\title{
The immersion freezing behavior of ash particles from wood and brown coal burning
}

\author{
Sarah Grawe ${ }^{1}$, Stefanie Augustin-Bauditz ${ }^{1}$, Susan Hartmann ${ }^{1}$, Lisa Hellner ${ }^{1}$, Jan B. C. Pettersson ${ }^{2}$, Andrea Prager ${ }^{3}$, \\ Frank Stratmann ${ }^{1}$, and Heike Wex ${ }^{1}$ \\ ${ }^{1}$ Leibniz Institute for Tropospheric Research, Leipzig, Germany \\ ${ }^{2}$ Department of Chemistry and Molecular Biology, University of Gothenburg, Gothenburg, Sweden \\ ${ }^{3}$ Leibniz Institute of Surface Modification, Leipzig, Germany \\ Correspondence to: Sarah Grawe (grawe@tropos.de)
}

Received: 10 March 2016 - Published in Atmos. Chem. Phys. Discuss.: 31 March 2016

Revised: 29 September 2016 - Accepted: 4 October 2016 - Published: 10 November 2016

\begin{abstract}
It is generally known that ash particles from coal combustion can trigger ice nucleation when they interact with water vapor and/or supercooled droplets. However, data on the ice nucleation of ash particles from different sources, including both anthropogenic and natural combustion processes, are still scarce. As fossil energy sources still fuel the largest proportion of electric power production worldwide, and biomass burning contributes significantly to the global aerosol loading, further data are needed to better assess the ice nucleating efficiency of ash particles. In the framework of this study, we found that ash particles from brown coal (i.e., lignite) burning are up to 2 orders of magnitude more ice active in the immersion mode below $-32^{\circ} \mathrm{C}$ than those from wood burning. Fly ash from a coal-fired power plant was shown to be the most efficient at nucleating ice. Furthermore, the influence of various particle generation methods on the freezing behavior was studied. For instance, particles were generated either by dispersion of dry sample material, or by atomization of ash-water suspensions, and then led into the Leipzig Aerosol Cloud Interaction Simulator (LACIS) where the immersion freezing behavior was examined. Whereas the immersion freezing behavior of ashes from wood burning was not affected by the particle generation method, it depended on the type of particle generation for ash from brown coal. It was also found that the common practice of treating prepared suspensions in an ultrasonic bath to avoid aggregation of particles led to an enhanced ice nucleation activity. The findings of this study suggest (a) that ash from brown coal burning may influence immersion freezing in clouds close to the source and (b) that the freezing behavior of ash
\end{abstract}

particles may be altered by a change in sample preparation and/or particle generation.

\section{Introduction}

Gaining a comprehensive knowledge of the formation and behavior of ice particles in clouds is of the utmost importance to achieve a better representation of ice-related processes in weather and climate models (Koop and Zobrist, 2009). Ice particles in clouds can be formed either by primary mechanisms, i.e., homogeneous and heterogeneous ice nucleation (Pruppacher and Klett, 1997), or by secondary mechanisms (Heymsfield and Willis, 2014, and references therein). In the atmosphere, homogeneous ice nucleation, i.e., the freezing of pure water or solution droplets, takes place at temperatures below $-38^{\circ} \mathrm{C}$ (Rosenfeld and Woodley, 2000; Koop et al., 2000; Murray et al., 2010a). At water saturation, this temperature limit of droplet freezing is raised in the presence of socalled ice nucleating particles (INPs) acting as catalysts for ice formation, which is then referred to as immersion freezing.

Combustion aerosol, accounting for a large fraction of the global aerosol loading, has been frequently investigated concerning its freezing behavior. It was discovered that soot (DeMott, 1990; Diehl and Mitra, 1998), metal oxides from furnaces and smelters (Szyrmer and Zawadzki, 1997), leadcontaining particles (Schäfer, 1975; Cziczo et al., 2009), and aerosol from biomass burning (Petters et al., 2009; Prenni et al., 2012; McCluskey et al., 2014) are able to act as INPs. 
To date, only a few studies on the freezing behavior of ash particles have been conducted (Schnell et al., 1976; Parungo et al., 1978a; Pueschel et al., 1979; Havlíček et al., 1989, 1993; Umo et al., 2015). Ash is defined as the solid material, which remains after the combustion of organic substances (e.g., fossil fuels, biofuels, and plant parts). It mainly consists of noncombustible components in the fuel such as mineral inclusions and of so-called heteroatoms, i.e., atoms other than carbon and hydrogen (Flagan and Seinfeld, 1988). This is what separates ash from carbonaceous particles, e.g., soot. During the combustion process, a fraction of fine ash particles is directly emitted into the atmosphere together with flue gases, whereas coarse ash particles mainly remain in the fireplace, boiler, or on the ground after a wildfire and may be lofted by the action of wind (Andreae et al., 2004). The former is termed "fly ash"; the latter is referred to as "bottom ash".

The globally increasing electric power demand is expected to continue to be covered by fossil fuels, making power generation by coal combustion grow faster than all renewable energy sources put together (International Energy Agency, 2012). Besides ash being the primary coal combustion byproduct (Kalyoncu and Olson, 2001), ash particles are also formed during biomass burning including wildfires. The impact of ash particles as potential INPs must be put into perspective by comparing ash emission rates to those of other INP-containing aerosols, e.g., mineral dust which is present in the atmosphere in abundance. An estimate for fly ash from coal combustion yields global annual emissions of $30 \mathrm{Mt}$ in the year 2000 (Smil, 2008), whereas global annual dust emissions are estimated to be as high as 700 to $3000 \mathrm{Mt}$ per year (Textor et al., 2006). As there are no further values concerning the number and distribution of different types of ash in the atmosphere, it is a difficult task to assess their impact on heterogeneous ice nucleation on a larger scale. DeMott et al. (2003), who examined atmospheric particles regarding their ability to function as INPs at cirrus temperatures over a period of 20 days, give a value of approximately $7 \%$ of ice crystal residues, which were formed under conditions favorable to heterogeneous nucleation, to be fly ash particles. The horizontal dispersion of these particles has been shown by Zhang et al. (2011), who found fly ash in surface snow crystal residues at a remote central Asian glacier. Backward air mass trajectories indicated that the particles originated from strongly populated areas to the west of the sampling site and were transported over thousands of kilometers through the high-level westerly jet stream. It must be mentioned that the chemical composition of mineral dust and ash is very similar, i.e., both include several common mineral components such as $\mathrm{Si}, \mathrm{Na}, \mathrm{Ca}, \mathrm{Fe}$, and oxides (Cziczo et al., 2004). Because of this difficulty, DeMott et al. (2003) and Zhang et al. (2011) used the spherical shape of fly ash particles, originating from the combustion process in the furnace, as a criterion to distinguish from other particle types. A discussion about the atmospheric relevance of coal fly ash particles in terms of their influence on heterogeneous ice nucleation can be found in Sect. 4.

Already in the 1960s, first presumptions arose that aerosol particles in the plumes of coal-fired power plants might be efficient at nucleating ice. Reasons for this were observations of ice fog (Benson, 1965) and so-called "industrial snow" (Agee, 1971; Parungo et al., 1978b) in close proximity to the stacks. Laboratory studies showed that coal fly ash particles are able to serve as INPs in the deposition (Parungo et al., 1978a; Havlíček et al., 1993) and immersion modes (Havlíček et al., 1989, 1993). Apart from untreated fly ash samples, Havlíček et al. (1993) also investigated the freezing behavior of the insoluble fraction alone and found up to 3 orders of magnitude less INPs in samples freed from water soluble components in comparison to the untreated samples at $-15^{\circ} \mathrm{C}$. Additionally, Havlíček et al. (1993) found that water soluble components, which were dominantly composed of anhydrous $\mathrm{CaSO}_{4}$, were responsible for differences in the ice nucleation ability of fly ash samples from different power plants. In comparison to coal fly ash, bottom ashes from coal and biomass burning have been rarely investigated. Recently, Umo et al. (2015) conducted first experiments on the immersion freezing behavior of bottom ash particles from coal and wood burning and compared the results to the ice nucleation ability of coal fly ash. These measurements were done with the help of a cold stage setup (Murray et al., 2010a; Whale et al., 2015). For Umo et al. (2015), droplets from $0.1 \mathrm{wt} \%$ ash-water suspensions were firstly pipetted ( $\mu \mathrm{L}$ droplets) and secondly nebulized ( $\mathrm{nL}$ droplets) onto a glass slide, which was placed on a cooled plate. The samples were investigated in temperature ranges from -12 to $-36^{\circ} \mathrm{C}$ (bottom ash) and from -16 to $-31{ }^{\circ} \mathrm{C}$ (coal fly ash). It was shown that bottom ashes nucleate ice in the immersion mode. Additionally, it was found that the fly ash particles are more efficient at nucleating ice than the bottom ash particles in a temperature range from -17 to $-27^{\circ} \mathrm{C}$. At $-20^{\circ} \mathrm{C}$ there is a difference of 2 orders of magnitude in $n_{\mathrm{s}}$ when comparing coal fly ash to the most efficient of the bottom ashes. The bottom ashes differed from each other by 2 orders of magnitude in $n_{\mathrm{s}}$, with wood bottom ash being the most efficient and coal bottom ash being the least efficient at nucleating ice. Umo et al. (2015) suggest that the different fuels and combustion temperatures causing changes in composition and morphology are the reason for the difference between bottom ash and fly ash.

As information concerning the ice nucleation efficiency of ash particles is still sparse, further investigations are needed to work out differences and similarities between the freezing behavior of ashes of varying origin and composition. In the present study, the immersion freezing behavior of five different ash samples, similar but not identical to those investigated by Umo et al. (2015), was quantified at the Leipzig Aerosol Cloud Interaction Simulator (LACIS; Hartmann et al., 2011). With our experimental setup, it was possible to study the influence of particle generation on the measured ice fractions 
as particles were produced both by dispersion of dry sample material and atomization of ash-water suspensions. Suspensions were prepared according to the method described in Umo et al. (2015), which includes treatment in an ultrasonic bath and subsequent stirring. As similar procedures are often used in the sample preparation for ice nucleation experiments, the effect of ultrasonic treatment of the sample on the immersion freezing behavior was investigated as well.

\section{Methods and materials}

\subsection{Experimental setup}

\subsubsection{Particle generation and size selection}

Airborne ash particles were generated in two different ways: (a) dispersion of dry sample material and (b) atomization of ash-water suspensions. Airborne particles from dry ash were generated using an aerosol generator consisting of a tilted glass bottle connected to an electric imbalance motor (Rösch, 2015). Dry ash particles situated at the bottom of the bottle become airborne along with particle-free pressurized air streaming into the bottle through a tube. Coarse material, which does not leave the bottle through the outlet at the top and deposits on its walls, is continually transported downwards. This is due to vibrations caused by the motor and the mounting of the bottle at a certain angle. The efficiency of the aerosol generator can be enhanced by mixing millimetersized glass beads into the samples, which was done for the fine sample material in this study. We do not expect the beads to have any influence on the surface properties of the particles, as only a small number of 20 beads were used which did not appear milky after several hours of particle generation. In addition to this herein called dry particle generation, particles were generated from an ash-water suspension using a custom-built atomizer (similar to TSI Model 3076) and a diffusion dryer unit. In the following, this procedure will be referred to as wet particle generation.

Before the aerosol was brought to a bipolar charge equilibrium inside a neutralizer, particles passed a cyclone (cut-off diameter $450 \mathrm{~nm}$ ) which was installed to minimize the number of multiply charged particles. After each set of measurements with LACIS, lasting usually $20 \mathrm{~min}$, the cyclone was cleaned. For all experiments presented here, $300 \mathrm{~nm}$ particles were selected by means of a differential mobility analyzer (DMA, Vienna type, medium; Knudson and Whitby, 1975); $300 \mathrm{~nm}$ particles were chosen because, at this size, there were sufficiently high and stable number concentrations for each of the five ash samples. Furthermore, industrial particle removal techniques tend to be less efficient for submicron particles (Flagan and Seinfeld, 1988), which is supported by size distribution measurements downstream of a coal-fired power plant featuring a bimodal distribution with a second mode diameter at $300 \mathrm{~nm}$ (Parungo et al., 1978a). Selecting other par- ticle sizes could be expected to lead to differences in freezing behavior due to a size dependent particle composition and/or morphology (Wheeler et al., 2014). However, in the case of bottom ash, measurements were performed with $500 \mathrm{~nm}$ brown coal bottom ash particles which showed no difference in $n_{\mathrm{S}}$ within the range of our measurement uncertainty compared to the measurements with $300 \mathrm{~nm}$ particles as will be demonstrated later (see Fig. 5). For fly ash we would not expect to see a size dependence of $n_{\mathrm{s}}$, at least not in the size range we are able to select, because there is evidence that the chemical composition of fly ash particles with aerodynamic diameters between 0.2 and $4.8 \mu \mathrm{m}$ is remarkably consistent (Kaufherr and Lichtman, 1984).

As for insoluble substances the ice nucleation efficiency depends on the surface area of the INP (Archuleta et al., 2005; Welti et al., 2009; Pinti et al., 2012; Hartmann et al., 2016), multiply charged particles in the investigated aerosol are more ice active than singly charged particles due to the presence of a larger surface area. To account for the multiply charged particles, measurements were performed with an U1tra High Sensitivity Aerosol Spectrometer (UHSAS, DMT, Boulder, CO, USA). An example of the UHSAS measurements with dry generated brown coal fly ash particles after size selection can be seen in Fig. 1. Note that the UHSAS detects the optical particle diameter which is smaller than the electrical mobility diameter in the shown example. To determine the multiple charge fractions, a four-modal normal distribution was fit to the measured data and the respective integrals were determined. In this case, we found $79.8 \%$ singly, $18.9 \%$ doubly, $0.9 \%$ triply, and $0.4 \%$ quadruply charged particles; i.e., the triply and quadruply charged particles contribute only $6 \%$ to the total surface area. Because of the low fraction of particles with three or more negative charges, which was in the range of $1 \%$ for all of the dry dispersed ash samples, only the doubly charged particles (fractions given in Table 1) were accounted for the correction of the immersion freezing experimental results. A detailed explanation of the multiple charge correction procedure is given by Hartmann et al. (2016).

A cloud condensation nuclei counter $(\mathrm{CCNc}, \mathrm{CCN}-100$, DMT, Boulder, CO, USA; Roberts and Nenes, 2005) was operated at certain times to investigate the hygroscopicity of size-selected particles. Care had been taken to set up similarly long sampling lines from the DMA to LACIS, the UH$\mathrm{SAS}$, and the CCNc in order to avoid a difference in particle losses.

\subsubsection{LACIS}

The immersion freezing behavior of the previously generated and size-selected ash particles was investigated with LACIS. In comparison to cold stage methods, where a set of suspension droplets is brought onto a cooled surface, LACIS offers the opportunity to examine airborne droplets. Furthermore, as water is brought into the system via the gas phase, im- 


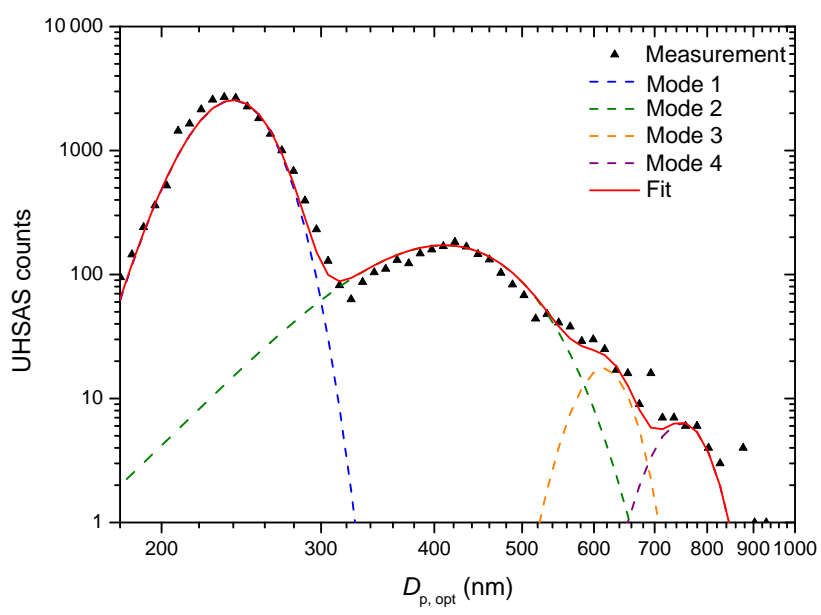

Figure 1. UHSAS measurements of dry dispersed brown coal fly ash particles after size selection of $300 \mathrm{~nm}$ particles with a DMA. Shown is a mean over the first $30 \mathrm{~min}$ of dry particle generation. The red line represents the least squares fit of a four-modal normal distribution to the measurement. The integrals over each of the four modes represent the number of singly, doubly, triply, and quadruply charged particles. Here, the multiple charge fractions were determined to $79.8 \%$ singly, $18.9 \%$ doubly, $0.9 \%$ triply, and $0.4 \%$ quadruply charged particles.

purities which are known to cause the freezing of pure water droplets above the homogeneous freezing limit on cold stages (Budke and Koop, 2015; Whale et al., 2015) can be ruled out for our experiments. LACIS consists of seven connected $1 \mathrm{~m}$ long tube sections with an inner diameter of $15 \mathrm{~mm}$. The $2 \mathrm{~mm}$ wide particle beam, surrounded by humidified, particle-free sheath air, is situated along the center line of the tube. As each of the seven sections can be temperature controlled individually with the help of thermostats, particles pass along defined temperature and saturation profiles. For the measurements presented here, LACIS was operated in a way that each particle was activated to a droplet in the second to last section. Further cooling caused a certain fraction of droplets, hereafter referred to as ice fraction $f_{\text {ice }}$, to freeze within a nucleation time of $1.6 \mathrm{~s}$. The discrimination between supercooled droplets and ice particles was realized with the help of the Thermo-stabilized Optical Particle Spectrometer for the detection of Ice (TOPS-Ice; Clauss et al., 2013). The approach to determining the phase state of the hydrometeors is based on the fact that the former polarization of light is maintained for scattering at spherical hydrometeors (supercooled water droplets) while non-spherical hydrometeors (ice particles) cause depolarization.

For each measurement at a given temperature, at least 2000 particles were detected. Due to this large number of counted particles and the small temperature uncertainty of $\pm 0.3 \mathrm{~K}$, LACIS measurements are very reproducible.
Table 1. Fractions of doubly charged particles generated from dry sample material as determined from UHSAS measurements. The selected particle size was $300 \mathrm{~nm}$. The fraction of particles with three or more negative charges was determined to be in the range of $1 \%$ for all samples and hence neglected.

\begin{tabular}{lc}
\hline Sample & Doubly charged fraction \\
\hline Spruce bottom ash & 0.12 \\
Birch bottom ash & 0.24 \\
Beech bottom ash & 0.06 \\
Brown coal bottom ash & 0.07 \\
Brown coal fly ash & 0.19 \\
\hline
\end{tabular}

\subsection{Sample preparation and characterization}

Five different kinds of ash were investigated concerning their immersion freezing behavior (see Table 2). While LACIS measurements were performed with all five samples from dry generation, only selected samples were also generated from a suspension. This is due to the fact that we chose not to investigate those samples further which already featured an ice nucleation efficiency close to the TOPS-Ice detection limit for dry particle generation. Bottom ashes from spruce, birch, and beech burning were examined to study the effect of wood type on the freezing behavior of the respective ash particles. Wood logs including bark were burned without the addition of leave material or small branches. The wood was stored for drying prior to the combustion process. It has to be noted that the coal bottom and fly ashes stem from lignite burning but will be referred to as "brown coal ash", corresponding to the generic term. The brown coal bottom and fly ash were not produced from brown coal with identical compositions. All bottom ash samples were taken from domestic heaters after the combustion of the pure substances. The fly ash sample was extracted from the electrostatic precipitators of the Lippendorf power station, which is situated $15 \mathrm{~km}$ south of Leipzig, Germany, and has a power output of $1840 \mathrm{MW}$.

Dry samples were placed in the aerosol generator without further preparations. The ash-water suspensions were prepared as described in Umo et al. (2015) with bottom ash from brown coal and spruce burning, as well as fly ash from brown coal burning. For this, a suspension of $0.05 \mathrm{wt} \%$ ash in Milli$\mathrm{Q}^{\circledR}$ water was placed in an ultrasonic bath (RK100H Sonorex Super, BANDELIN electronic GmbH \& Co. KG, Berlin, Germany) for $10 \mathrm{~min}$. According to Umo et al. (2015), this step is necessary to break down ash aggregates. It has already been shown that the size distribution of soil particles in a suspension can be modified by ultrasonic dispersion (Oorts et al., 2005). To see whether a treatment with the ultrasonic bath influences the ice nucleation efficiency of the suspension particles as well, a fly ash suspension sample was prepared without ultrasonic treatment. Afterwards, all samples were stirred for $\approx 24 \mathrm{~h}$. Additionally to this procedure, part of the brown coal fly ash suspension sample was filtered us- 
Table 2. Sample overview with temperature range in which ice nucleation (IN) was observed.

\begin{tabular}{lllll}
\hline \multirow{2}{*}{ Ash type } & $\begin{array}{l}\text { Combustion } \\
\text { material }\end{array}$ & $\begin{array}{l}\text { Dry generation } \\
\text { IN observed } T \text { range }\end{array}$ & $\begin{array}{l}\text { Wet generation +US } \\
\text { IN observed } T \text { range }\end{array}$ & $\begin{array}{l}\text { Wet generation }- \text { US } \\
\text { IN observed } T \text { range }\end{array}$ \\
\hline \multirow{2}{*}{ Bottom ash } & Wood (spruce) & $\leq-35^{\circ} \mathrm{C}$ & $\leq-34^{\circ} \mathrm{C}$ & - \\
& Wood (birch) & $\leq-35^{\circ} \mathrm{C}$ & - & - \\
& Wood (beech) & $\leq-35^{\circ} \mathrm{C}$ & - & - \\
& Brown coal & $\leq-32^{\circ} \mathrm{C}$ & $\leq-35^{\circ} \mathrm{C}$ & - \\
\hline Fly ash & Brown coal & $\leq-27{ }^{\circ} \mathrm{C}$ & $\leq-24^{\circ} \mathrm{C}$ & $\leq-34^{\circ} \mathrm{C}$ \\
\hline
\end{tabular}

ing syringe filters (200 $\mathrm{nm}$ pore size, Millex ${ }^{\mathrm{TM}}$, Merck KGaA, Darmstadt, Germany) to remove the majority of fly ash particles from the suspension and leave water soluble material.

Four of the dry samples were investigated by means of inductively coupled plasma-sector field mass spectrometry (ICP-SFMS; Zheng and Yamada, 2006) at ALS Scandinavia $\mathrm{AB}$ (Luleå, Sweden). Beech bottom ash was provided late in the course of the experiments and hence not analyzed for its chemical composition. Figure 2 and Table 3 show the results of the chemical composition analysis, i.e., the mass fractions of certain oxides and elements. The former were estimated by recalculating the measured concentrations of major ions into their most common oxide forms. Any missing percentage is due to other than the major elements and the fact that other counterions were involved. For example, apart from $\mathrm{K}_{2} \mathrm{O}, \mathrm{K}$ may also occur in the form of $\mathrm{KCl}$ or $\mathrm{K}_{2} \mathrm{CO}_{3}$.

Fly ash from brown coal burning contains $15 \%$ more $\mathrm{SiO}_{2}$ than any other sample which qualitatively corresponds to findings by Umo et al. (2015). Also, bottom ash from brown coal burning includes $4 \%$ more $\mathrm{SiO}_{2}$ than spruce bottom ash and $12 \%$ more than birch bottom ash. However, the wood bottom ashes contain more $\mathrm{K}_{2} \mathrm{O}$ than those from coal burning. This is an important point because $\mathrm{K}$ in biomass burning ash, in contrast to $\mathrm{K}$ in coal ash, is largely water soluble (Steenari et al., 1999b) and might influence its ice nucleation efficiency. As for single elements, it is most striking that the brown coal ashes include $\mathrm{Hg}$, which cannot be found in the wood ash samples. Suggestions on how these differences might affect the immersion freezing behavior of the different ash types can be found in Sect. 3 .

To investigate particle shape and surface properties, scanning electron microscope (SEM) images were taken. Bottom and fly ash particles from dry and wet generation with electrical mobility diameters of $D_{\mathrm{p}, \mathrm{el}}=300 \mathrm{~nm}$ were generated as described in Sect. 2.1.1, collected on Nuclepore $^{\mathrm{TM}}$ track-etched membrane polycarbonate filters (Sigma-Aldrich, St. Louis, MO, USA), and pictured by the SEM. Figure 3 shows images of (a) brown coal bottom ash (dry generation), (b) brown coal fly ash (dry generation), (c) spruce bottom ash (wet generation), and (d) brown coal fly ash (wet generation). The high number of particles larger than $300 \mathrm{~nm}$ in Fig. 3a is due to the fact that the cyclone was not emptied sufficiently often during the several hours of
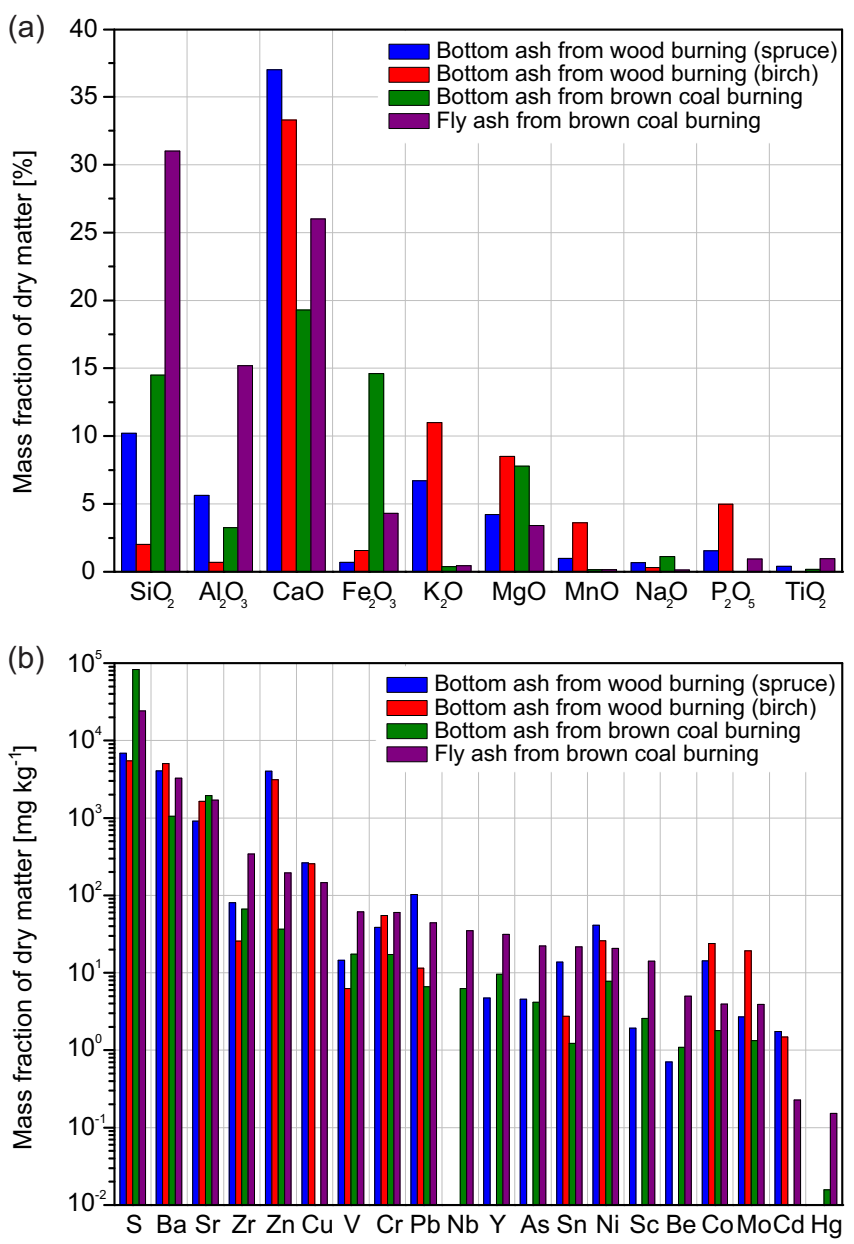

Figure 2. Mass fractions of (a) certain oxides and (b) additional elements in the dry matter of bottom ash from spruce, birch, and brown coal burning, as well as fly ash from brown coal burning. The analysis was performed by means of inductively coupled plasmasector field mass spectrometry (ICP-SFMS) at ALS Scandinavia AB (Luleå, Sweden). Table 3 shows the values given in the bar chart and the associated uncertainties.

collecting particles from dry generation, leading to a disproportionate accumulation of multiply charged particles which were not present in the LACIS experiments (experiments are terminated after $30 \mathrm{~min}$ at most because of wall glaciation 
Table 3. Mass fractions in percent of certain oxides and elements in the dry matter of bottom ash from spruce, birch, and brown coal burning, as well as fly ash from brown coal burning. The numbers given here correspond to the bars depicted in Fig. 2. The loss on ignition (LOI) test was performed at $1000^{\circ} \mathrm{C}$ to assess the completeness of the combustion processes.

\begin{tabular}{|c|c|c|c|c|c|c|c|c|}
\hline & $\begin{array}{r}\text { Spruce } \\
\text { bottom ash }\end{array}$ & $\begin{array}{r}\text { Uncertainty } \\
( \pm)\end{array}$ & $\begin{array}{r}\text { Birch } \\
\text { bottom ash }\end{array}$ & $\begin{array}{r}\text { Uncertainty } \\
( \pm)\end{array}$ & $\begin{array}{l}\text { Brown coal } \\
\text { bottom ash }\end{array}$ & $\begin{array}{r}\text { Uncertainty } \\
( \pm)\end{array}$ & $\begin{array}{r}\text { Brown coal } \\
\text { fly ash }\end{array}$ & $\begin{array}{r}\text { Uncertainty } \\
( \pm)\end{array}$ \\
\hline Oxide & \multicolumn{8}{|c|}{ Mass fraction of dry matter [\%] } \\
\hline $\mathrm{SiO}_{2}$ & 10.2 & 1.5 & 2.03 & 0.3 & 14.5 & 2.1 & 31 & 4.6 \\
\hline $\mathrm{Al}_{2} \mathrm{O}_{3}$ & 5.64 & 0.95 & 0.69 & 0.117 & 3.25 & 0.55 & 15.2 & 2.6 \\
\hline $\mathrm{CaO}$ & 37 & 6.2 & 33.3 & 5.6 & 19.3 & 3.3 & 26 & 4.4 \\
\hline $\mathrm{Fe}_{2} \mathrm{O}_{3}$ & 0.698 & 0.133 & 1.57 & 0.29 & 14.6 & 2.9 & 4.3 & 0.81 \\
\hline $\mathrm{K}_{2} \mathrm{O}$ & 6.7 & 1.35 & 11 & 2.2 & 0.392 & 0.078 & 0.451 & 0.09 \\
\hline $\mathrm{MgO}$ & 4.22 & 0.88 & 8.5 & 1.76 & 7.79 & 1.67 & 3.4 & 0.71 \\
\hline $\mathrm{MnO}$ & 0.988 & 0.134 & 3.61 & 0.48 & 0.164 & 0.022 & 0.148 & 0.02 \\
\hline $\mathrm{Na}_{2} \mathrm{O}$ & 0.67 & 0.125 & 0.321 & 0.06 & 1.12 & 0.21 & 0.144 & 0.027 \\
\hline $\mathrm{P}_{2} \mathrm{O}_{5}$ & 1.55 & 0.25 & 4.99 & 0.77 & 0.0211 & 0.0046 & 0.934 & 0.145 \\
\hline $\mathrm{TiO}_{2}$ & 0.412 & 0.075 & 0.0247 & 0.0045 & 0.178 & 0.037 & 0.969 & 0.175 \\
\hline$\sum$ & 68.1 & - & 66 & - & 61.3 & - & 82.5 & - \\
\hline LOI $\left(1000^{\circ} \mathrm{C}\right)$ & 22.9 & 5 & 26.7 & 5 & 10.5 & 5 & -0.8 & 5 \\
\hline Element & \multicolumn{8}{|c|}{ Mass fraction of dry matter $\left[\mathrm{mg} \mathrm{kg}^{-1}\right]$} \\
\hline As & 4.57 & 8.04 & $<3$ & - & 4.17 & 7.97 & 22.2 & 8.9 \\
\hline $\mathrm{Ba}$ & 4050 & 667 & 5060 & 827 & 1050 & 171 & 3260 & 557 \\
\hline $\mathrm{Be}$ & 0.708 & 0.271 & $<0.5$ & - & 1.09 & 0.34 & 4.98 & 0.87 \\
\hline $\mathrm{Cd}$ & 1.75 & 0.34 & 1.48 & 0.31 & $<0.1$ & - & 0.228 & 0.135 \\
\hline Co & 14.2 & 3.2 & 23.9 & 5.4 & 1.79 & 0.56 & 3.93 & 0.98 \\
\hline $\mathrm{Cr}$ & 38.5 & 7.2 & 54.7 & 10 & 17.3 & 3.3 & 60.1 & 11 \\
\hline $\mathrm{Cu}$ & 263 & 57 & 256 & 56 & $<10$ & - & 146 & 32 \\
\hline $\mathrm{Hg}$ & $<0.01$ & - & $<0.01$ & - & 0.0157 & 0.0047 & 0.152 & 0.032 \\
\hline Mo & 2.69 & - & 19.2 & 3.5 & 1.33 & - & 3.92 & - \\
\hline $\mathrm{Nb}$ & $<5$ & - & $<5$ & & 6.26 & 0.93 & 34.8 & 4.9 \\
\hline $\mathrm{Ni}$ & 41.2 & 9.9 & 25.9 & 6.2 & 7.8 & 2.04 & 20.6 & 5 \\
\hline $\mathrm{Pb}$ & 103 & 21 & 11.5 & 2.8 & 6.61 & 2.01 & 44.4 & 9.1 \\
\hline $\mathrm{S}$ & 6830 & - & 5460 & - & 83000 & - & 24200 & - \\
\hline $\mathrm{Sc}$ & 1.93 & 0.63 & $<0.9$ & - & 2.58 & 0.66 & 14.1 & 2.8 \\
\hline Sn & 13.8 & - & 2.75 & - & 1.23 & - & 21.6 & - \\
\hline $\mathrm{Sr}$ & 913 & 137 & 1640 & 250 & 1940 & 313 & 1700 & 280 \\
\hline V & 14.5 & 2.2 & 6.27 & 1.18 & 17.4 & 2.3 & 61.1 & 7.9 \\
\hline W & $<50$ & - & $<50$ & - & $<50$ & - & $<50$ & - \\
\hline Y & 4.74 & 0.72 & $<2$ & - & 9.6 & 1.41 & 31.3 & 4.6 \\
\hline $\mathrm{Zn}$ & 4010 & 782 & 3120 & 613 & 36.4 & 7.9 & 195 & 38 \\
\hline $\mathrm{Zr}$ & 80.1 & 20.2 & 25.6 & 6.4 & 66.7 & 18 & 341 & 45 \\
\hline
\end{tabular}

effects). We did not observe this accumulation for wet particle generation. For further examination of this issue, we performed an additional experiment in which we used an aerodynamic particle sizer (APS, TSI model 3321) in addition to the UHSAS to detect the particle size distribution after size selection. It was observed that, after roughly $30 \mathrm{~min}$ of sampling from dry particle generation, the fraction of supermicron particles increased strongly. Cleaning of the cyclone removed the occurrence of these supermicron particles. While the cyclone was only cleaned every few hours during the sampling of the filter shown in Fig. 3a, it was cleaned every $30 \mathrm{~min}$ for the filters sampled later on (see Fig. 3b). On these, only singly and doubly charged particles occurred where the fraction of doubly charged particles derived from counting was in agreement with the respective UHSAS measurements (see Table 1).

The direct comparison of the brown coal ashes from dry generation shows differences in particle shape: the bottom ash particles appear more irregular and fractal-like than the fly ash particles. This difference might be related to the carbon content of the two samples as particles with high carbon content tend to develop irregular structures due to aggregation (Hiranuma et al., 2008). From the loss on ignition analysis (LOI, see Table 3), we know that the brown coal bot- 

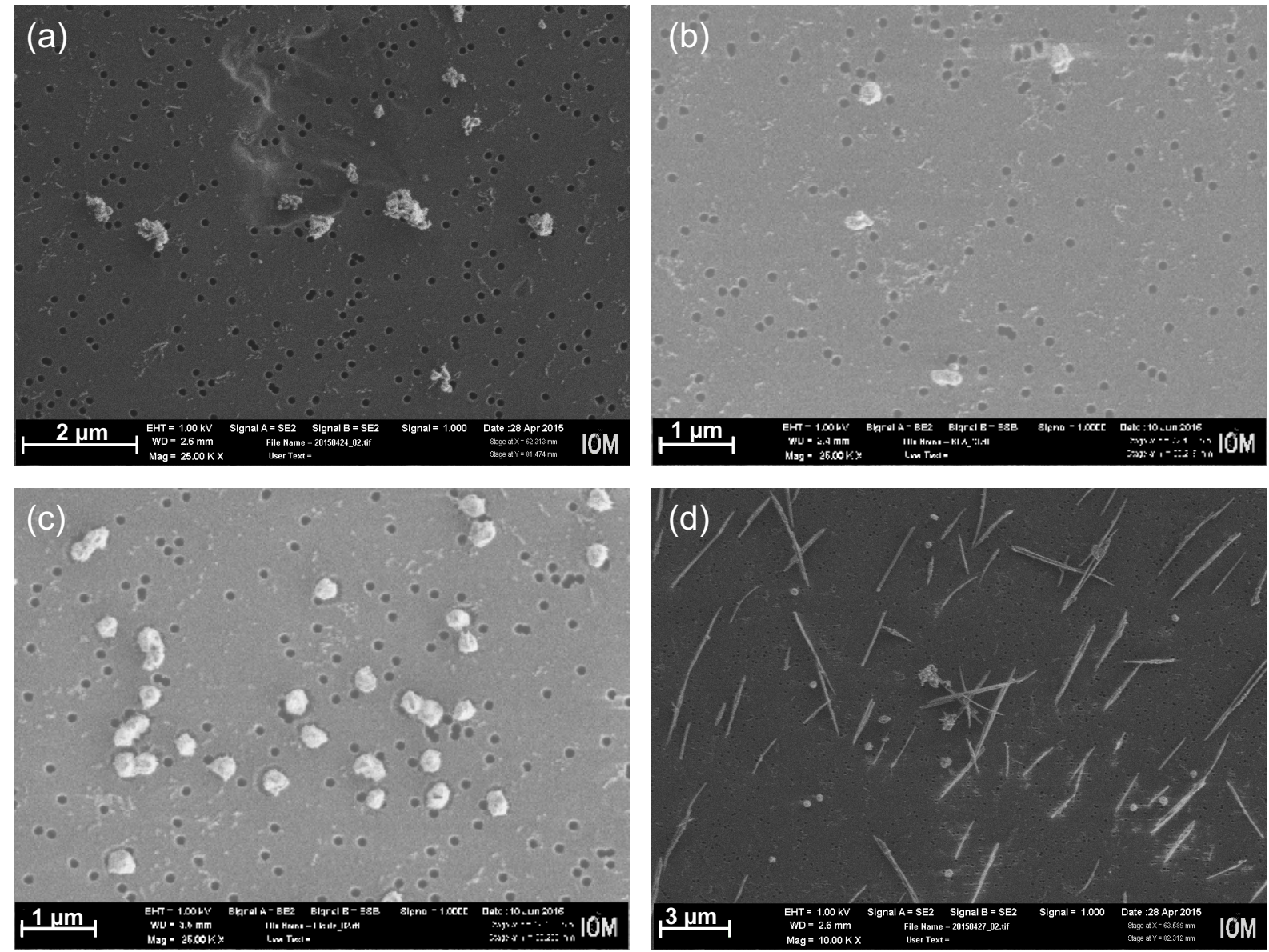

Figure 3. Scanning electron microscope (SEM) images of (a) bottom ash particles from brown coal burning (dry generation), (b) fly ash particles from brown coal burning (dry generation), (c) bottom ash particles from spruce burning (wet generation), and (d) fly ash particles from brown coal burning (wet generation). In each case particles with $D_{\mathrm{p}, \mathrm{el}}=300 \mathrm{~nm}$ were selected. Note the different magnification.

tom ash still contains $11 \%$ of unburnt fuel, i.e., carbonaceous particles which form during incomplete combustion (Kucbel et al., 2016). The brown coal combustion in the power plant, however, was very efficient, as no organic fraction, i.e., no carbon could be found in this sample. This observation is supported by specific surface area measurements of coal fly ash and bottom ash from coal and biomass burning, where the lowest value was detected for fly ash (Umo et al., 2015).

Apart from a small number of $300 \mathrm{~nm}$ sized fly ash particles, the SEM image of brown coal fly ash particles from wet generation (see Fig. 3d) shows a majority of particles that seem to be needle-shaped crystals. These crystals appear to be several microns long. It is reasonable to assume that the crystals consist of water soluble components which exist in the suspension separated from the fly ash particles. Inside the atomizer, droplets are formed which can consist of either only soluble material or additional insoluble particles. The subsequent drying process supposedly leads to a crystallization of the soluble components. This crystal formation does not take place in the experiments by Umo et al. (2015) as droplets are directly produced from the suspension. In this case, the components which are present in the crystals are dissolved in the droplets. There are several possible implications from the presence of crystals in the immersion freezing experiments with fly ash suspension particles, which will be discussed in Sect. 3. Possibly, $\mathrm{CaCO}_{3}$ is the dominant phase of the water soluble fraction. During the combustion process, $\mathrm{CaO}$ is produced (present in the initial sample; see Fig. 2 and Table 3) which may react with $\mathrm{H}_{2} \mathrm{O}$ to form $\mathrm{Ca}(\mathrm{OH})_{2}$. $\mathrm{CaCO}_{3}$ may form from $\mathrm{Ca}(\mathrm{OH})_{2}$ upon reaction with $\mathrm{CO}_{2}$ from the air (Steenari et al., 1999b). That we do not see any needles on the SEM image of spruce ash suspension particles (Fig. 3c), even though this sample contains $11 \%$ more $\mathrm{CaO}$ than the fly ash sample, is possibly due to the variety of different crystal shapes which $\mathrm{CaCO}_{3}$ is known to occur in and which include needles, hexagonal plates, and others (Kim et al., 2009). Particularly hexagonal plates might not be as easily distinguishable from the insoluble particles as the prominent needles and might be seen, at least to some 
extent, in Fig. 3c, where the resolution of the pictures unfortunately does not allow a better analysis.

The presence of $\mathrm{Ca}$ in the needles was confirmed by investigating filter samples by means of Scanning Electron Microscopy coupled with Energy Dispersive X-ray (SEM/EDX) spectroscopy. However, there is no definite proof that $\mathrm{CaCO}_{3}$ is the dominant phase of the water soluble fraction of fly ash particles from wet generation. It has to be mentioned that Havlíček et al. (1993) found a majority of $\mathrm{CaSO}_{4}$ in the soluble fractions of most of their investigated fly ash samples. This is unlikely for our fly ash sample as the amount of $\mathrm{S}$ was below the detection limit of the EDX on all of the examined filter sections.

In addition to the above discussed samples, a filtered fly ash suspension sample was also used to generate sizesegregated particles. These were then also collected and examined under the SEM (not shown here). Almost none of the approximately spherical insoluble fly ash particles were observed under the SEM, from which it can be interpreted that the filtering process removed the insoluble material almost entirely. We are referring to the remaining compounds as "water soluble" even though we are aware that insoluble material smaller than the filter pore size of $200 \mathrm{~nm}$ might still be present. This is justified because the selected $300 \mathrm{~nm}$ particles predominantly include soluble substances. $\mathrm{CCNc}$ measurements with particles from the filtered fly ash suspension indicate a low hygroscopicity $(\kappa=0.06 \pm 0.01)$. However, this does not necessarily mean that the components in the generated particles are not soluble. Sullivan et al. (2009) give a value of $\kappa=0.011$ for $\mathrm{CaCO}_{3}$, which is weakly soluble (Plummer and Busenberg, 1982). The generated particles could hence be composed of a mixture of $\mathrm{CaCO}_{3}$ and other compounds.

\section{Results and discussion}

The immersion freezing behavior of the five ash samples was investigated in a temperature range from -24 to $-40^{\circ} \mathrm{C}$. Figure 4 shows the obtained $f_{\text {ice }}$ values for particles from dry (see full circles in Fig. 4) and wet generation (see open circles in Fig. 4b, c, d). Four data sets were obtained for fly ash from brown coal burning (see Fig. 4d). These include $f_{\text {ice }}$ values of dry particles, suspended particles with ultrasonic treatment (+US), suspended particles without ultrasonic treatment (-US), and the water soluble material remaining in the filtered ash-water suspension (+US). The data for ash particles from dry generation were multiply charge corrected according to the method presented in Hartmann et al. (2016). A multiple charge correction was not possible for ash from wet particle generation because of the two particle populations (particles from soluble material and insoluble ash particles) causing overlapping signals in the UHSAS measurements. In Fig. 4, vertical error bars represent the standard deviation of three or more measurements. In case no error bar was added,
Table 4. Parameters for the model calculations based on the SBM. $\lambda$ is the ice fraction in the saturation range, $\mu$ the mean contact angle, and $\sigma$ the standard deviation of the contact angle distribution. The clay mineral baseline corresponds to different kinds of mineral dust which featured a similar immersion freezing behavior after coating with sulfuric acid.

\begin{tabular}{lccc}
\hline & $\lambda$ & $\mu(\mathrm{rad})$ & $\sigma(\mathrm{rad})$ \\
\hline Augustin-Bauditz et al. (2014) & & & \\
\hline Clay mineral baseline & 0.40 & 1.82 & 0.12 \\
Feldspar & 1.84 & 1.30 & 0.10 \\
\hline This work & & & \\
\hline Brown coal bottom ash dry & 0.87 & 1.60 & 0.08 \\
Brown coal fly ash dry & 1.91 & 1.40 & 0.07 \\
Brown coal fly ash wet (+US) $\cdot 4.54$ & 0.24 & 1.13 & 0.10 \\
\hline
\end{tabular}

the shown data point is either a mean of two measurements or originates from a single measurement.

Additionally, model calculations of three of the measured data sets (fly and bottom ash from brown coal burning, dry particle generation; fly ash from brown coal burning, wet particle generation +US) are included in Fig. 4, together with previous measurements of mineral dust (Augustin-Bauditz et al., 2014) for comparison. The calculations are based on the Soccer Ball Model (SBM) as described in Niedermeier et al. (2015). In the SBM, the ice nucleation activity of a sample is described using a contact angle distribution with $\mu$ and $\sigma$ being its mean and standard deviation. The average number of INPs per droplet $\lambda$ was determined according to Hartmann et al. (2013) after a similar approach by Vali (1971):

$\lambda=-\ln \left(1-f_{\text {ice }}^{*}\right)$,

where $f_{\text {ice }}^{*}$ is the ice fraction in the temperature range in which $f_{\text {ice }}$ saturates. The values for $\lambda$, as well as $\mu$ and $\sigma$ can be found in Table 4. All SBM fit curves are shown as thick lines in the measured temperature range and as thin lines in the extrapolation range. The similar values for $\sigma$ indicate that there is a comparable variability of the contact angles for all investigated ash samples and the mineral dusts.

\subsection{Dry particle generation}

Figure 4a shows a significant difference between wood ashes and brown coal ashes. In the case of wood ash particles, $f_{\text {ice }}$ does not exceed $10 \%$ between -35 and $-37^{\circ} \mathrm{C}$. It is striking that the ice nucleation efficiency of all three examined wood ashes is very similar, which leads us to the conclusion that the influence of the burned wood type on the immersion freezing behavior of the bottom ash particles is small for the investigated samples. In this context, the amount of $\mathrm{K}$ in the wood ash could play a role. Although no chemical composition analysis was performed in the case of beech ash, it is known that wood ash in general contains K (Steenari et al., 1999a), 
(a) Dry particle generation

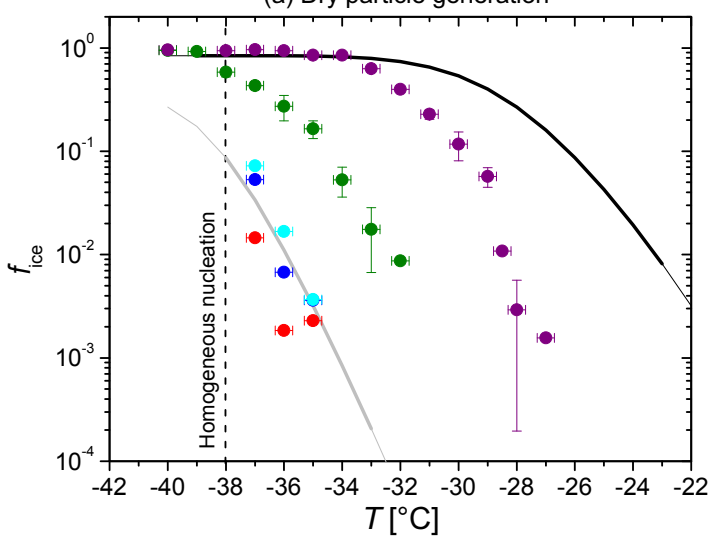

(b) Dry vs. wet particle generation: Spruce bottom ash

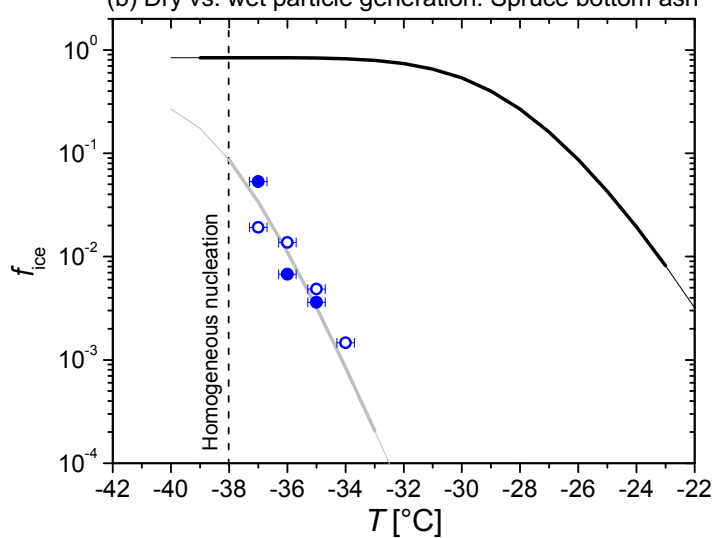

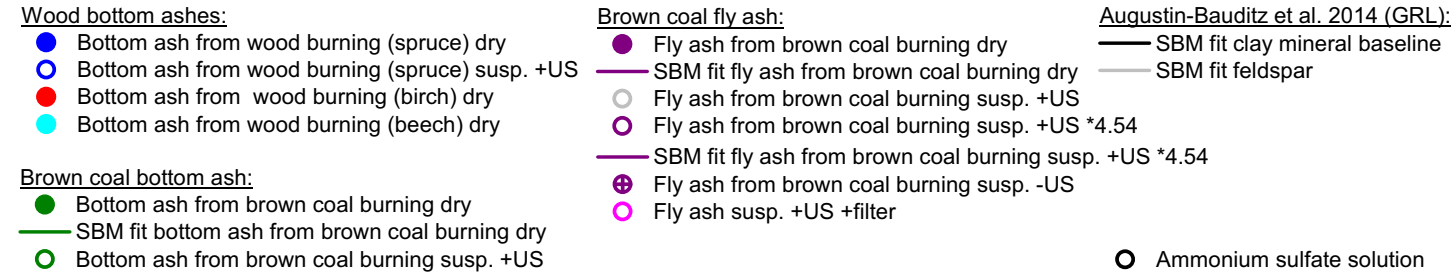

(c) Dry vs. wet particle generation: Brown coal bottom ash

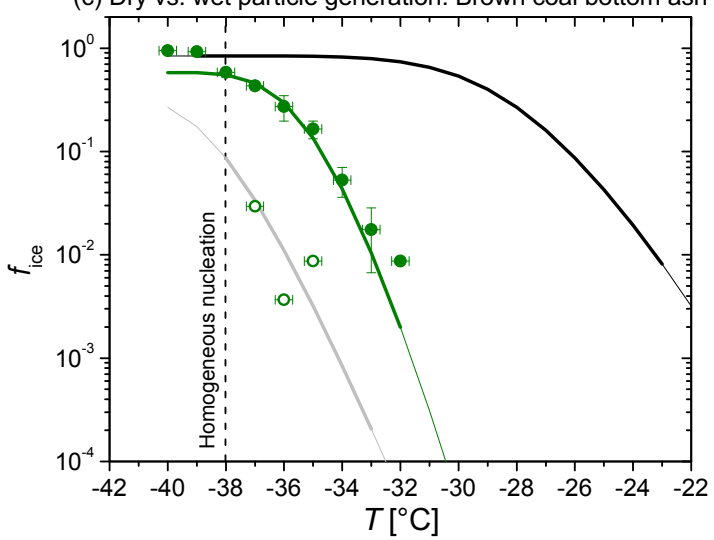

(d) Dry vs. wet particle generation: Brown coal fly ash

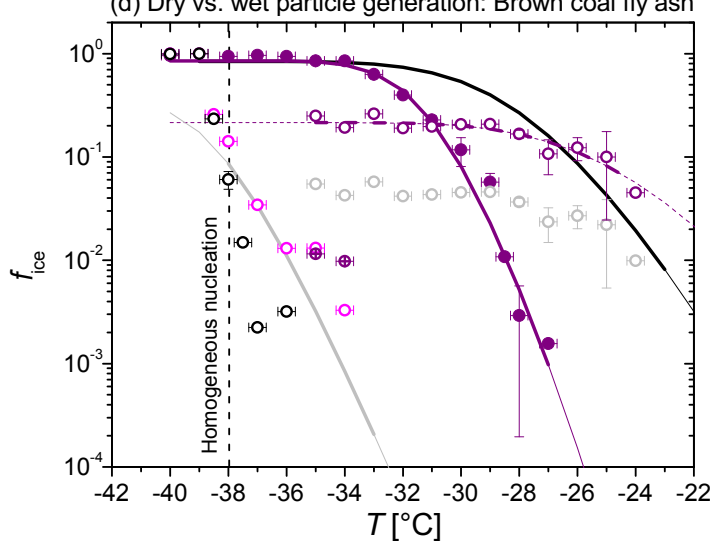

Figure 4. Ice fraction $f_{\text {ice }}$ as a function of temperature $T$ for ash particles from dry (full circles) and wet generation (open circles, $\mathbf{b}, \mathbf{c}, \mathbf{d}$ ) with $D_{\mathrm{p}, \mathrm{el}}=300 \mathrm{~nm}$. Error bars represent the LACIS temperature error of $0.3 \mathrm{~K}$ and the $f_{\text {ice }}$ standard deviation of three or more measurements, respectively. A scaling factor of 4.54 was applied to the fly ash suspension measurements to account for the occurrence of crystals during wet particle generation. The solid and dashed lines represent the SBM fits to selected samples from this work and to data published in AugustinBauditz et al. (2014), all for $D_{\mathrm{p}, \mathrm{el}}=300 \mathrm{~nm}$. Parameters for the SBM fits are given in Table 4. The feldspar sample from Augustin-Bauditz et al. (2014) is composed of $76 \%$ microcline (K-feldspar) and $24 \%$ albite (Na-feldspar). The clay mineral baseline corresponds to different kinds of mineral dust which featured a similar immersion freezing behavior after coating with sulfuric acid. The homogeneous region is determined by investigating the immersion freezing behavior of highly diluted ammonium sulfate droplets (black open circles, $\mathbf{d}$ ).

which has also been found in the here examined spruce and birch ash samples (see Fig. 2 and Table 3). Additionally, it has been shown that different wood ash samples contain similar amounts of K (Steenari et al., 1999a), justifying the assumption that the beech ash sample also contains $\mathrm{K}$ in amounts similar to the other two wood ashes. On the one hand, the fact that $\mathrm{K}$ in wood ashes is largely soluble, because it is present in the form of soluble salts and oxides (Steenari et al., 1999b), might be the reason for the low ice nucleation efficiency of the wood ashes. On the other hand, the supposedly similar amount of soluble K could be the reason for the comparable ice nucleation efficiency of the three investigated wood ashes.

In comparison to the wood ash, bottom and fly ashes from brown coal burning are more effective INPs in the immersion mode. Within these experiments, we can compare the onset freezing temperatures of the different samples. From these, it is apparent that the coal fly ash particles are more efficient 
than the coal bottom ash particles, as ice fractions above the optic's detection limit could be found at $-27^{\circ} \mathrm{C}$, whereas we were not able to detect ice nucleation activity for coal bottom ash particles until temperatures as cold as $-32^{\circ} \mathrm{C}$. Again, the ice nucleation efficiency of the coal ashes could be related to the $\mathrm{K}$ content because, in contrast to the soluble $\mathrm{K}$ in wood ash, coal ash contain $\mathrm{K}$ in clay minerals with low solubility (Steenari et al., 1999b).

To date, there is no experimental evidence on the icenucleation-determining characteristics in ash, presumably because it has rarely been studied and because it is a very complex mixture (Ramsden and Shibaoka, 1982; Umbría et al., 2004; Zhang et al., 2011). The chemical composition may influence the immersion freezing behavior and hence could be causing differences between the different kinds of ash. Apart from the differences in the $\mathrm{K}$ content, we found that the $\mathrm{SiO}_{2}$ concentration correlates with the ice nucleation efficiency of the investigated samples. As $\mathrm{SiO}_{2}$ has been shown to be ice active (Pruppacher and Sänger, 1955; Isono et al., 1959; Eastwood et al., 2008; Zimmermann et al., 2008; Atkinson et al., 2013), it might be an important component influencing the immersion freezing behavior of the brown coal ashes in comparison to one another and to the wood bottom ashes. However, even though this holds true for the ashes presented here, a larger number of samples would have to be investigated to make a conclusive statement. Another relevant component could be $\mathrm{Hg}$, as Mason and van den Heuvel (1959) found that $\mathrm{HgI}_{2}$ has the potential to act as INP. This previous observation may be relevant to our study as $\mathrm{Hg}$ was detected in the brown coal ashes but not in the wood bottom ashes.

Although studies dealing with the nature of active sites commonly investigated mineral dust particles, the findings might be transferable to other material systems such as ash. As for $\mathrm{SiO}_{2}$ (Zolles et al., 2015), the brown coal ash particles might be more efficient at nucleating ice because of surface defects such as lattice dislocations caused by impurities or crystallographic dislocations. The high ice nucleation efficiency of the fly ash particles could also be related to a large fraction of amorphous material (Umo et al., 2015, found more than $80 \%$ in a coal fly ash sample). As amorphous particles in fly ash are mainly composed of aluminosilicate glass (Ramsden and Shibaoka, 1982; Querol et al., 1996), the high content of $\mathrm{SiO}_{2}$ and $\mathrm{Al}_{2} \mathrm{O}_{3}$ in our fly ash sample in comparison to the bottom ashes could be an indication of a high amorphous fraction. It has been shown that amorphous organic aerosol particles are able to nucleate ice (Murray et al., 2010b; Wilson et al., 2012; Ignatius et al., 2016), but it remains to be examined whether amorphous components in fly ash are ice active as well.

To assess the ice nucleating ability of ash particles in comparison to mineral dust, Table 4 and Fig. 4 additionally show the parameters and fit curve to measurements with an untreated feldspar sample (76\% microcline (K-feldspar), and $24 \%$ albite (Na-feldspar); Augustin-Bauditz et al., 2014), which was the most efficient dust sample ever examined at LACIS so far. Also shown is the curve for different kinds of mineral dust particles (same feldspar sample, Arizona Test Dust, NX-illite, Fluka kaolinite) coated with sulfuric acid (Augustin-Bauditz et al., 2014). The coating caused all different dusts to show a similar immersion freezing behavior even though differences were observed without coating, presumably due to different amounts of K-feldspar contained in the samples. Weathering feldspars turns them into clay minerals and it was argued in Augustin-Bauditz et al. (2014) that the coating had a comparable effect, i.e., consuming all feldspars in the different samples and leaving clay minerals only. Hence the line on which the data from all the differently coated mineral dusts fell was termed the "clay mineral baseline". Comparing the dry wood bottom ash particles to the clay mineral baseline shows similarities with a tendency of wood bottom ashes being slightly less ice active than clay minerals. However, the brown coal ashes are more efficient at nucleating ice than the clay minerals, yet not as efficient as the feldspar sample. This can also be seen when comparing the mean of the contact angle distribution ( $\mu$ in Table 4) determined for brown coal bottom and fly ash (1.60 and 1.40, respectively) with those for the clay mineral baseline and the feldspar sample (1.82 and 1.30, respectively), where higher values correspond to ice nucleation activity at lower temperatures.

\subsection{Wet particle generation}

When comparing the results from dry and wet particle generation, it must be noted that a multiple charge correction was not possible for the latter due to overlapping signals in the UHSAS measurements caused by insoluble ash particles and soluble material. However, we estimated the multiple charge fractions in the suspension measurements by weighting the bipolar charge distribution (Wiedensohler, 1988) with measured size distributions. We found that the highest number of multiply charged particles was probably present in the experiments with the fly ash suspension with ultrasonic treatment ( $80.5 \%$ singly, $16.8 \%$ doubly, and $2.7 \%$ triply charged particles). Were we to perform the multiple charge correction using these fractions, our measured data would be reduced by a maximum factor of 2 only. There is a caveat to this estimate, as crystals will probably have been present during the size distribution measurements as well and we cannot be sure how the size distributions would look for the insoluble particles only.

In Fig. $4 \mathrm{~b}$ it can be seen that in the case of spruce bottom ash the ultrasonic treatment and stirring process did not affect the ice nucleation ability considerably. The ice nucleation efficiency of the brown coal bottom ash suspension sample (+US, Fig. 4c), however, is reduced by $20 \%$ at $-35^{\circ} \mathrm{C}$ due to the change in sample preparation and particle generation.

For the filtered fly ash suspension sample, the $f_{\text {ice }}$ values (magenta open circles in Fig. 4d) are comparable to what 
was found for similarly sized droplets containing one $300 \mathrm{~nm}$ ammonium sulfate particle each (black open circles); i.e., droplets grown on these particles showed solely homogeneous freezing behavior. This supports the hypothesis that the needle-shaped crystals occurring during wet particle generation are likely composed of water soluble material. As a result, a solid substrate for heterogeneous ice nucleation is missing and droplets containing the material from a single crystal each freeze due to homogeneous nucleation only. The immersion freezing behavior of the sample hence originates solely from the insoluble fly ash particles and our measurements need to be corrected with respect to the occurrence of the crystals. As mentioned in Sect. 2.2, the crystalline soluble particles were also observed in the form of hexagonal plates. However, this difference in shape does not influence the size distribution of the cloud droplets in LACIS as high supersaturations $(>10 \%)$ ensure that every particle is activated. Hence, only the fraction of crystalline particles in comparison to the insoluble particles was determined. For this, SEM images of particles from the non-filtered fly ash suspension (+US) were analyzed. By counting $\approx 900$ particles, it was determined that $\approx 78 \% \pm 3 \%$ of all particles are crystals (uncertainty calculated from the $95 \%$ confidence limit). This value may be smaller in the flow tube as the fragile crystals might break upon impact on the filter, leading to a multiplication. Assuming that only $22 \%$ of the droplets contained an insoluble fly ash particle during the experiments with the suspension sample, the original data (gray open circles) were corrected by a factor of $1 / 0.22=4.54$, which is also shown (purple open circles) for a direct comparability to the ice nucleation ability of dry particles from the same sample. This correction should be seen as an upper limit for $f_{\text {ice }}$ of the fly ash suspension particles, the lower limit would correspond to the original data (gray open circles).

In the plateau region below $-31^{\circ} \mathrm{C}$, a maximum of $25 \%$ of all insoluble fly ash particles from suspension is ice active, which is a clear lowering of the ice nucleation activity by a factor of almost 4 in the plateau region compared to dry particle generation; i.e., suspending the particles in water reduced their ice nucleation efficiency in the temperature range below $-31^{\circ} \mathrm{C}$. Note that this lowering might be larger depending on the multiple charge fractions in the case of wet particle generation. However, fly ash suspension particles are more efficient at nucleating ice in the temperature range from -24 to $-31^{\circ} \mathrm{C}$ compared to fly ash particles from dry generation. These differences are, as for brown coal bottom ash but apparently not for spruce bottom ash, related to a change of physical and/or chemical particle properties due to the change in particle generation. A change in particle composition has been observed before for mineral dust particles which featured different hygroscopicities when being generated firstly via dry dispersion and secondly via atomization (Herich et al., 2009; Sullivan et al., 2010). It was assumed that soluble material present in a fraction of the dry particles was redistributed across all particles contained in the droplets as a coating (Herich et al., 2009). Sullivan et al. (2010) state that changes in surface structure and chemistry from dry to wet particle generation might not only affect the hygroscopicity but also the ice nucleation behavior of the particles.

Furthermore, it is interesting to see that the $f_{\text {ice }}$ values of the fly ash suspension which was not put in the ultrasonic bath are clearly lower than those of the fly ash suspension with ultrasonic treatment. Here, it is valid to compare to the uncorrected curve of the sample with ultrasonic treatment (gray open circles in Fig. 4d), assuming a similar, or smaller, crystal fraction in the dispersed sample without ultrasonic treatment. The observed increase in ice nucleation efficiency for the sample with ultrasonic treatment might be related to the fragmentation of large particles in the ultrasonic bath and the redistribution to smaller grain sizes associated therewith (Oorts et al., 2005). The freshly exposed surface could feature an increased number of defects serving as active sites, which would then be comparable to the increase in ice nucleation efficiency of mineral dust particles after milling (Hiranuma et al., 2014; Zolles et al., 2015). It must be mentioned that the enhancing effect of ultrasonic treatment on the immersion freezing behavior has been observed before during experiments with soil dust at LACIS (Hellner, 2015). As there are many publications describing the use of an ultrasonic bath during sample preparation in order to avoid aggregation and for resuspension purposes (e.g., Zobrist et al., 2008; Stetzer et al., 2008; Eastwood et al., 2009; Chernoff and Bertram, 2010; O'Sullivan et al., 2015; Umo et al., 2015), we recommend cautiousness since this practice alters particle properties in a way that may lead to larger ice fractions in the immersion mode.

\subsection{Comparison to previous results}

In the next step, the ice nucleation active surface site density $n_{\mathrm{s}}$ was determined from the measured $f_{\text {ice }}$ according to the singular approach (DeMott, 1995; Connolly et al., 2009; Niemand et al., 2012):

$n_{\mathrm{s}}=-\frac{\ln \left(1-f_{\text {ice }}\right)}{A_{\mathrm{p}}}$.

For this, the particles were assumed to be spherical with a surface area of $A_{\mathrm{p}}=4 \pi\left(D_{\mathrm{p}} / 2\right)^{2}$, the diameter $D_{\mathrm{p}}$ corresponding to the electrical mobility diameter of the selected particles $(300 \mathrm{~nm})$. In the case of fly ash from wet particle generation, the corrected $f_{\text {ice }}$, i.e., multiplied by factor 4.54 , was used for the calculation of $n_{\mathrm{s}}$. In taking the particle surface area into account and assuming a time-independent behavior, a comparability to results obtained from experimental setups other than LACIS is made possible.

Figure 5 shows $n_{\mathrm{s}}$ for ash particles from dry and wet generation in comparison to the results published by Umo et al. (2015). Identical colors indicate similar fuels and combustion conditions. Umo et al. (2015) used a cold stage setup, where each droplet contains numerous ash particles, i.e., a large 


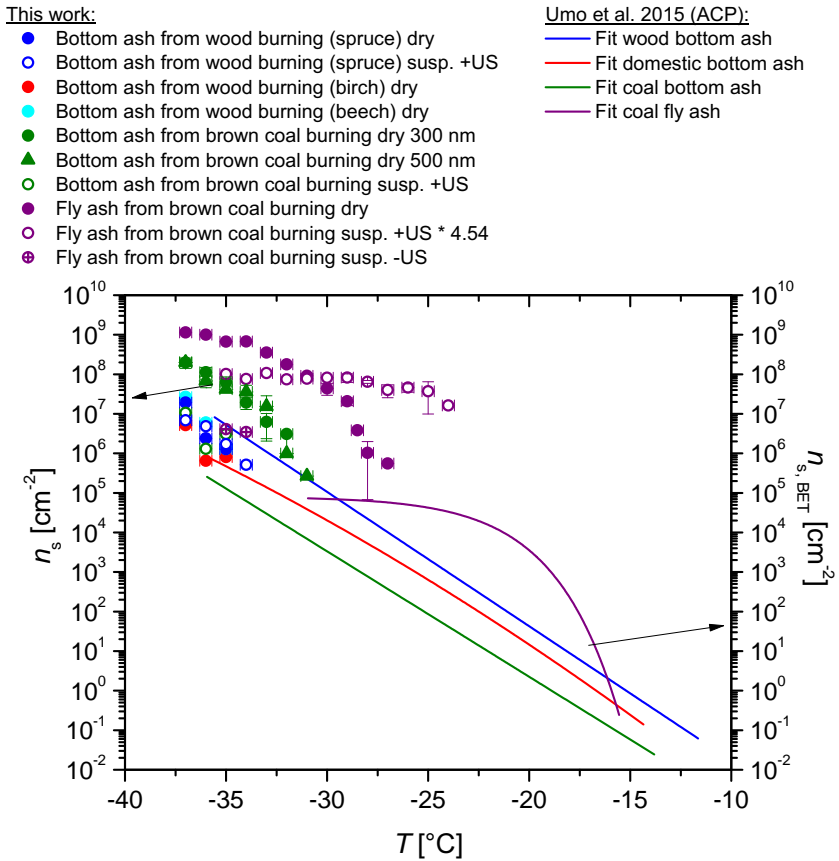

Figure 5. Comparison of ice nucleation surface site density $n_{\mathrm{S}}$ as a function of temperature $T$ for ash particles from dry (full circles: $300 \mathrm{~nm}$ particles, triangles: $500 \mathrm{~nm}$ particles) and wet generation (open circles: $300 \mathrm{~nm}$ particles) with results by Umo et al. (2015, lines). For the LACIS measurements, the particle surface area was determined assuming spherical particles (left ordinate), whereas the $n_{\mathrm{s}}$ values reported by Umo et al. (2015) are based on the BET specific surface area of the particles (right ordinate).

available INP surface area, leading to an increase in freezing probability in comparison to LACIS measurements. As a result, Umo et al. (2015) investigated the immersion freezing behavior of ash particles in a high temperature range $(\approx-12$ to $-35^{\circ} \mathrm{C}$ ) and there is a limited overlap in comparison to our measurements. Apart from the contrasting measurement principle, another methodological difference is the determination of the particle surface area. Umo et al. (2015) used a Brunauer-Emmett-Teller (BET; Brunauer et al., 1938) nitrogen gas adsorption method, which yields specific surface area values. A second ordinate was introduced in Fig. 5 to differentiate between our $n_{\mathrm{S}}$ values, assuming spherical particles (circles, left ordinate) and the BET specific surface area determined $n_{\mathrm{s}}$ values reported by Umo et al. (2015) (lines, right ordinate).

All wood bottom ashes, either from dry or wet particle generation, fit the data by Umo et al. (2015) (wood: commercially available solid wood fuel; domestic: unspecified soft and hard woods) within 1 order of magnitude. However, for brown coal bottom ash, only the suspension particles yield $n_{\mathrm{s}}$ values close to what Umo et al. (2015) found for a comparable sample, while the respective dry generated particles show $n_{\mathrm{s}}$ values that are 2 orders of magnitude larger at the same temperature. The $n_{\mathrm{S}}$ values determined from LACIS measurements with $500 \mathrm{~nm}$ brown coal bottom ash particles (triangles) are similar to what was found for $300 \mathrm{~nm}$ particles, indicating that particle properties causing ice nucleation scale with the surface area. In the case of brown coal fly ash, we observe a plateau between -24 and $-32^{\circ} \mathrm{C}$, which can also be seen in the measurements by Umo et al. (2015). However, our results are 3 orders of magnitude higher in $n_{\mathrm{s}}$. This difference might decrease slightly, bearing in mind that $n_{\mathrm{S}}$ for the fly ash suspension particles could be lower depending on the actual fraction of needle-shaped crystals in the flow tube (with the deviation still being at least 2 orders of magnitude in $n_{\mathrm{S}}$ ).

To make sure that this disagreement is not caused by the difference in particle surface area determination, we also calculated BET-based $n_{\mathrm{s}}$ values for our measurements. For this, the particle surface area was determined according to $A_{\mathrm{p}}=\rho \cdot V_{\mathrm{p}} \cdot \mathrm{SSA}$, with $\rho$ the ash density taken from the literature (wood bottom ash: $827 \mathrm{~kg} \mathrm{~m}^{-3}$, according to Naik et al., 2001; brown coal bottom ash: $1415 \mathrm{~kg} \mathrm{~m}^{-3}$, according to U.S. Department of Transportation, 1998; brown coal fly ash: $2456 \mathrm{~kg} \mathrm{~m}^{-3}$, according to Shoumkova et al., 2005), $V_{\mathrm{p}}$ the particle volume assuming a spherical shape and a diameter of $300 \mathrm{~nm}$, and SSA the specific surface area reported by Umo et al. (2015) from BET measurements (wood bottom ash: $6.98 \mathrm{~m}^{2} \mathrm{~g}^{-1}$; coal bottom ash: $8.86 \mathrm{~m}^{2} \mathrm{~g}^{-1}$; coal fly ash: $2.54 \mathrm{~m}^{2} \mathrm{~g}^{-1}$ ). It must be noted that the BET specific surface area is a sample specific quantity. However, as similar materials were combusted at similar conditions, we may assume that the BET values reported by Umo et al. (2015) are comparable to those of our samples. With this, $n_{\mathrm{s} \text {, BET values }}$ derived from our data would even increase, by a maximum factor of 3.5 in comparison to the $n_{\mathrm{S}}$ values shown as circles in Fig. 5, meaning that effects other than the difference in surface area determination must be responsible for the discrepancy between our data set and that by Umo et al. (2015).

To estimate a possible influence of particle non-sphericity on $n_{\mathrm{s}}$, one could assume a dynamic shape factor of $\chi=1.25$, which was observed for atmospheric dust particles (Kaaden et al., 2009) but which is likely much larger than $\chi$ for the here examined ash particles. This would only account for a lowering in $n_{\mathrm{s}}$ by a factor of 1.4. Even a much larger $\chi$ of 1.57 as given by Hinds (1999) for sand would only increase $n_{\mathrm{s}}$ by a factor of 1.9. So overall, omitting the possible effects of non-sphericity, as was done in this work, only accounts for comparably small changes in $n_{\mathrm{s}}$ and cannot explain the difference between our fly ash sample and the one examined by Umo et al. (2015). Although a time dependence of the nucleation process has been observed before (Ervens and Feingold, 2012; Welti et al., 2012; Wex et al., 2014), this effect would also be too small to describe the here found discrepancies. It is more likely, that the change in particle generation, e.g., the extended time that the ash particles spend in suspension, leads to a change of the particle properties causing ice nucleation. During this prolonged time in compari- 
son to the few seconds from droplet activation to ice nucleation, other compounds and/or a higher number of previously partly dissolved compounds could enter the solution leading to a decrease in ice nucleation efficiency. For example, Peckhaus et al. (2016) observed the dissolution of different elements from feldspar samples continuing for weeks. Furthermore, there are recent studies investigating the effect of different experimental methods on the ice nucleation behavior where most cold stage methods yielded lower $n_{\mathrm{s}}$ values than dry dispersion methods (Hiranuma et al., 2015; Emersic et al., 2015). Hiranuma et al. (2015) argue that a high degree of agglomeration in the dry-dispersed particle measurements leads to a larger surface area being exposed to liquid water and consequently larger $n_{\mathrm{S}}$ values in comparison to the rather de-agglomerated suspensions. In contrast, Emersic et al. (2015) present the hypothesis that particles may coalesce in suspension, leading to enhanced sedimentation and therefore a reduction of the surface area available for ice nucleation. Even though these studies investigated mineral dust particles, the findings could equally be applied to our ash samples. Differences in ice nucleation efficiency between our samples and those investigated by Umo et al. (2015) could also be related to differences in composition due to size selection. In our case, the immersion freezing behavior of $300 \mathrm{~nm}$ particles was investigated, whereas the suspensions examined by Umo et al. (2015) contained much larger particles (average volume-equivalent diameters of 10 and $8 \mu \mathrm{m}$ for coal fly ash and bottom ash, respectively). This might be relevant as there are studies indicating that the trace elemental composition in fly ash is inversely proportional to the particle size in the supermicron range and not strongly size dependent for submicron particles (Davison et al., 1974; Smith et al., 1979).

\section{Atmospheric implications}

There is evidence indicating that fly ash particles can be transported over several hundreds of kilometers to remote locations (Hicks and Isaksson, 2006; Li and Shao, 2009; Zhang et al., 2011; Rose et al., 2012) because, as stated earlier, industrial particle removal techniques are less efficient for small (i.e., submicron) particles. In the case of wood bottom ash, millimeter-sized particles may also stay airborne for hours because of their low density and convoluted shape (Andreae et al., 2004). In addition to the emission during combustion, ash may also be lofted into the atmosphere from dry ash disposal sites, i.e., during unloading off a truck and driving across the ash surface (Mueller et al., 2013).

Reliable information on the global emission of ash particles, especially biomass burning ash, is scarce, which is why it is difficult to evaluate their impact on heterogeneous ice nucleation on a large scale. However, we would like to present a rough estimate on INP concentrations from fly ash emissions close to the source based on previous findings.
Emission rates of coal fly ash are strongly dependent on the efficiency of the particle removal technique in the power plant. The horizontal and vertical plume dispersion depends on the meteorological conditions (temperature of surrounding air, stratification, wind direction and speed), as well as the exit velocity from the stacks and the stack height (Seinfeld and Pandis, 2006; Hinneburg et al., 2009). For simplicity and due to the lack of in-stack size distribution measurements downstream of the electrostatic precipitator, we assume a monodisperse population of $300 \mathrm{~nm}$ sized fly ash particles. In the case of the Lippendorf power plant, particulate emissions and flue gasses are released over two naturaldraught cooling towers, which are $174.5 \mathrm{~m}$ high. On average, $32000 \mathrm{t}$ of brown coal are burned daily, which, according to an estimate by Querol et al. (1996), results in the production of $6400 \mathrm{t}$ of fly ash. As the electrostatic precipitator has an efficiency of $99.98 \%, 0.02 \%$ of this mass are emitted. This corresponds to $1.3 \mathrm{t}$ of fly ash and eventually to a number of $N_{\mathrm{p}}=4 \times 10^{19}$ spherical fly ash particles with a diameter of $300 \mathrm{~nm}$, assuming a density of $2456 \mathrm{~kg} \mathrm{~m}^{-3}$ (Shoumkova et al., 2005). To estimate the particle number concentration $C$ at the exit, it is necessary to assess the volume flow $Q$ from both towers and therefore the exit velocity $v_{\mathrm{e}}$. This was done by evaluating video recordings of the plume rise close to the exit. On average, $v_{\mathrm{e}}=6 \mathrm{~m} \mathrm{~s}^{-1}$ was observed which is consistent with the mean exit velocity from natural-draught cooling towers given by Fisher (1997). $C$ can be estimated according to

$C \approx \frac{N_{\mathrm{p}}}{Q t}$ with $Q \approx \frac{N_{\mathrm{t}}}{4} \pi d_{\mathrm{t}}^{2} v_{\mathrm{e}}$.

Here, the time $t$ is $24 \mathrm{~h}$, because we consider the daily coal consumption, $N_{\mathrm{t}}=2$ is the number of cooling towers, and $d_{\mathrm{t}}=75 \mathrm{~m}$ is the cooling tower diameter. This estimation yields a particle number concentration of $\approx 8000 \mathrm{~cm}^{-3}$ at the cooling tower exit. From airborne size distribution measurements performed by Parungo et al. (1978a), we know the total number concentration in a stable plume 35 and $80 \mathrm{~km}$ downstream of a coal-fired power plant, which is 3510 and $2710 \mathrm{~cm}^{-3}$, respectively. At the same time, the total background concentration was determined to be $1100 \mathrm{~cm}^{-3}$. This would correspond to an atmospheric dilution factor of $\approx 3$ to 5 for this specific set of meteorological conditions. With $n_{\mathrm{s}}=5.55 \times 10^{5} \mathrm{~cm}^{-2}$ at $-27^{\circ} \mathrm{C}$ (fly ash from dry particle generation, taken from Fig. 5), we can calculate $f_{\text {ice }}$ for the differently sized ash particles in the plume and from that, together with the information on the size distribution taken from Parungo et al. (1978a), estimate the atmospheric INP concentrations related to the ash particles in the plume. This approximation was done assuming that $n_{\mathrm{s}}$ is equal for different particle sizes and that the fly ash particles are the only component of the plume aerosol nucleating ice. Also, only particles in the submicron size range were considered. From our estimate, we found that $1.8 \mathrm{~cm}^{-3}$ are active INPs at a temperature of $-27^{\circ} \mathrm{C}$ at a distance of $35 \mathrm{~km}$ downstream 
of the power plant cooling towers and still $1.3 \mathrm{~cm}^{-3} 80 \mathrm{~km}$ downstream. These values are well above typical INP concentrations of $10^{-4}$ to $10^{-2} \mathrm{~cm}^{-3}$ reported in the literature (Pruppacher and Klett, 1997; Rogers et al., 1998; DeMott et al., 2010; Petters and Wright, 2015). In conclusion, it can be said that the impact of fly ash particles on immersion freezing in mixed-phase clouds can be significant in close proximity to the power plant at sufficiently low temperatures. However, to make a conclusive statement, one would have to model the horizontal and vertical dispersion of fly ash in the plume depending on the meteorological parameters and power plant characteristics.

\section{Summary and conclusions}

In the framework of this study, the immersion freezing behavior of ash particles has been investigated in a temperature range from -24 to $-40^{\circ} \mathrm{C}$. Airborne aerosol particles of $300 \mathrm{~nm}$ in size were generated from five different combustion ash samples and analyzed at LACIS. The samples included bottom ash from spruce, birch, and beech burning, bottom ash from brown coal burning, and fly ash from brown coal burning.

It was found that there are differences in the immersion freezing behavior of dry dispersed bottom ash from wood burning and the two brown coal ash samples, the latter showing a significantly higher ice nucleating efficiency. Bottom and fly ash from brown coal burning initiated freezing at temperatures as high as -33 and $-29^{\circ} \mathrm{C}$, respectively, whereas the examined wood ashes were observed to nucleate ice only below $-35^{\circ} \mathrm{C}$. It was shown that the brown coal ashes are more efficient at nucleating ice than sulfuric-acid-coated mineral dusts (Augustin-Bauditz et al., 2014) yet not as efficient as the feldspar sample used by Augustin-Bauditz et al. (2014). The investigation of the chemical composition gave no definite indication of what exactly causes the differences between wood and coal ashes, but a number of different factors were discussed. Investigating further particle properties which have been shown to influence freezing behavior such as lattice structure, surface chemical configuration, number and type of surface defects, and ability of the surface to participate in electrostatic interactions (Shen et al., 1977; Yakobi-Hancock et al., 2013; Zolles et al., 2015; Kulkarni et al., 2015) might be the key to understanding the differences between different kinds of ash.

Furthermore, measurements were conducted with ash particles from suspensions which were prepared by putting them in an ultrasonic bath followed by a $24 \mathrm{~h}$ stirring process. This was done for bottom ashes from spruce and brown coal burning, as well as fly ash from brown coal burning. LACIS measurements showed barely any change in the ice nucleation efficiency of bottom ash from spruce burning. In contrast, a difference due to the change in particle generation was observed for the brown coal ashes. SEM images of the fly ash suspension particles were taken on which we observed a majority of needle-shaped crystals and some insoluble fly ash particles. The crystals may have formed from soluble components, likely $\mathrm{CaCO}_{3}$, in the drying process. After a potential ice nucleation activity of the crystals was excluded, a correction of the determined $n_{\mathrm{s}}$ values was performed with respect to the fraction of insoluble fly ash particles. As the results do not match the $f_{\text {ice }}$ and $n_{\mathrm{s}}$ spectra of fly ash particles from dry generation, it can be concluded that the difference in immersion freezing behavior is caused by a change in particle properties from dry to wet particle generation which has been observed before for mineral dusts (Herich et al., 2009; Sullivan et al., 2010). Eventually, another fly ash suspension sample without ultrasonic treatment was prepared for which we only observed a very low ice nucleation activity below $-34{ }^{\circ} \mathrm{C}$. This could imply that previous studies using ultrasonification might have overestimated the ice nucleation ability of certain substances. Hence, we advise being cautious when using an ultrasonic bath for sample preparation prior to freezing experiments.

Regarding previous investigations on the immersion freezing of ash particles, we found that the wood bottom ashes, either from wet or dry particle generation, show similar $f_{\text {ice }}$ and $n_{\mathrm{s}}$ spectra in comparison to the samples examined by Umo et al. (2015). However, brown coal bottom ash only features a comparable immersion freezing behavior to the sample investigated by Umo et al. (2015) when particles are being generated from a suspension. It is striking that, although the shape of the $n_{\mathrm{s}}$ spectrum of our brown coal fly ash suspension particles is similar to the one observed by Umo et al. (2015) in the overlap area, $n_{\mathrm{s}}$ is higher by up to 3 orders of magnitude. This discrepancy cannot be explained by the difference in particle surface area determination and therefore is most likely related to the physical and/or chemical properties of the two fly ash samples and the difference in methodology (flow tube vs. cold stage).

To summarize, we found the ice nucleation activity of brown coal bottom and fly ash to be similar to mineral dusts. However, bulk ash is a very heterogeneous material containing several different particle types (Ramsden and Shibaoka, 1982; Umbría et al., 2004; Zhang et al., 2011), which complicates the interpretation of experimental results. More work has to be done in the field of sample characterization to identify features that cause differences in the immersion freezing behavior of different kinds of ash. Complementary to experimental data on the freezing behavior of ash particles, more information is needed about the atmospheric abundance of these particles. As reliable estimates of global ash emissions are missing, this knowledge can only be acquired by developing feasible methods to clearly distinguish between mineral dusts and ash particles in the framework of in situ measurements. A long-term objective is the implementation of parameterizations of ash particles as INPs into weather and climate models. 


\section{Data availability}

The datasets are available upon request to the contact author and will be stored in a publicly accessible database in the near future.

Acknowledgements. This research was conducted in the framework of the DFG funded Ice Nuclei research UnIT (INUIT, FOR 1525), WE 4722/1-2. We would like to thank the staff of the Lippendorf power station for providing the fly ash sample as well as Paul Herenz and Markus Hartmann, who performed and evaluated the $\mathrm{CCNc}$ measurements.

Edited by: Daniel J. Cziczo

Reviewed by: Y. Boose and three anonymous referees

\section{References}

Agee, E. M.: An artificially induced local snowfall, B. Am. Meteor. Soc., 52, 557-560, 1971.

Andreae, M. O., Rosenfeld, D., Artaxo, P., Costa, A. A., Frank, G. P., Longo, K. M., and Silva-Dias, M. A. F.: Smoking rain clouds over the Amazon, Science, 303, 1337-1342, 2004.

Archuleta, C. M., DeMott, P. J., and Kreidenweis, S. M.: Ice nucleation by surrogates for atmospheric mineral dust and mineral dust/sulfate particles at cirrus temperatures, Atmos. Chem. Phys., 5, 2617-2634, doi:10.5194/acp-5-2617-2005, 2005.

Atkinson, J. D., Murray, B. J., Woodhouse, M. T., Whale, T. F., Baustian, K. J., Carslaw, K. S., Dobbie, S., O'Sullivan, D., and Malkin, T. L.: The importance of feldspar for ice nucleation by mineral dust in mixed-phase clouds, Nature, 498, 355-358, 2013.

Augustin-Bauditz, S., Wex, H., Kanter, S., Ebert, M., Niedermeier, D., Stolz, F., Prager, A., and Stratmann, F.: The immersion mode ice nucleation behavior of mineral dusts: A comparison of different pure and surface modified dusts, Geophys. Res. Lett., 41, 7375-7382, 2014.

Benson, C.: Ice fog: Low temperature air pollution, U.S. Army CRREL Research Report 121, 1965.

Brunauer, S., Emmett, P. H., and Teller, E.: Adsorption of gases in multimolecular layers, J. Am. Chem. Soc., 60, 309-319, 1938.

Budke, C. and Koop, T.: BINARY: an optical freezing array for assessing temperature and time dependence of heterogeneous ice nucleation, Atmos. Meas. Tech., 8, 689-703, doi:10.5194/amt-8689-2015, 2015.

Chernoff, D. I. and Bertram, A. K.: Effects of sulfate coatings on the ice nucleation properties of a biological ice nucleus and several types of minerals, J. Geophys. Res., 115, D20205, doi:10.1029/2010JD014254, 2010.

Clauss, T., Kiselev, A., Hartmann, S., Augustin, S., Pfeifer, S., Niedermeier, D., Wex, H., and Stratmann, F.: Application of linear polarized light for the discrimination of frozen and liquid droplets in ice nucleation experiments, Atmos. Meas. Tech., 6, 1041-1052, doi:10.5194/amt-6-1041-2013, 2013.

Connolly, P. J., Möhler, O., Field, P. R., Saathoff, H., Burgess, R., Choularton, T., and Gallagher, M.: Studies of heterogeneous freezing by three different desert dust samples, Atmos. Chem. Phys., 9, 2805-2824, doi:10.5194/acp-9-2805-2009, 2009.
Cziczo, D., Stetzer, O., Worringen, A., Ebert, M., Weinbruch, S., Kamphus, M., Gallavardin, S. J., Curtius, J., Borrmann, S., Froyd, K. D., Mertes, S., Möhler, O., and Lohmann, U.: Inadvertent climate modification due to anthropogenic lead, Nature Geosci., 2, 333-336, 2009.

Cziczo, D. J., Murphy, D. M., Hudson, P. K., and Thomson, D. S.: Single particle measurements of the chemical composition of cirrus ice residue during CRYSTAL-FACE, J. Geophys. Res., 109, doi:10.1029/2003JD004032, 2004.

Davison, R. L., Natusch, D. F., and Wallace, J. R.: Trace elements in fly ash: Dependence of concentration on particle size, Environ Sci. Technol., 8, 1107-1113, 1974.

DeMott, P. J.: An exploratory study of ice nucleation by soot aerosols, J. Appl. Meteorol., 29, 1072-1079, 1990.

DeMott, P. J.: Quantitative descriptions of ice formation mechanisms of silver iodide-type aerosols, Atmos. Res., 38, 63-99, 1995.

DeMott, P. J., Cziczo, D. J., Prenni, A. J., Murphy, D. M., Kreidenweis, S. M., Thomson, D. S., Borys, R., and Rogers, D. C.: Measurements of the concentration and composition of nuclei for cirrus formation, P. Natl. Acad. Sci., 100, 14655-14660, 2003.

DeMott, P. J., Prenni, A. J., Liu, X., Kreidenweis, S. M., Petters, M. D., Twohy, C. H., Richardson, M. S., Eidhammer, T., and Rogers, D. C.: Predicting global atmospheric ice nuclei distributions and their impacts on climate, P. Natl. Acad. Sci., 107, 11217-11222, 2010.

Diehl, K. and Mitra, S. K.: A laboratory study of the effects of a kerosene-burner exhaust on ice nucleation and the evaporation rate of ice crystals, Atmos. Environ., 32, 3145-3151, 1998.

Eastwood, M. L., Cremel, S., Gehrke, C., Girard, E., and Bertram, A. K.: Ice nucleation on mineral dust particles: Onset conditions, nucleation rates and contact angles, J. Geophys. Res., 113, D22203, doi:10.1029/2008JD010639, 2008.

Eastwood, M. L., Cremel, S., Wheeler, M., Murray, B. J., Girard, E., and Bertram, A. K.: Effects of sulphuric acid and ammonium sulfate coatings on the ice nucleation properties of kaolinite particles, Geophys. Res. Lett., 36, L02811, doi:10.1029/2008GL035997, 2009.

Emersic, C., Connolly, P. J., Boult, S., Campana, M., and Li, Z.: Investigating the discrepancy between wet-suspension- and drydispersion-derived ice nucleation efficiency of mineral particles, Atmos. Chem. Phys., 15, 11311-11326, doi:10.5194/acp15-11311-2015, 2015.

Ervens, B. and Feingold, G.: On the representation of immersion and condensation freezing in cloud models using different nucleation schemes, Atmos. Chem. Phys., 12, 5807-5826, doi:10.5194/acp-12-5807-2012, 2012.

Fisher, B. E.: Predicting cooling tower plume dispersion, Proceedings of the Institution of Mechanical Engineers. Part A: Journal of Power and Energy, 211, 291-297, 1997.

Flagan, R. C. and Seinfeld, J. H.: Fundamentals of Air Pollution Engineering, chap. Particle formation in combustion, 358-390, Prentice-Hall, Inc., Englewood Cliffs, New Jersey, 1988.

Hartmann, S., Niedermeier, D., Voigtländer, J., Clauss, T., Shaw, R. A., Wex, H., Kiselev, A., and Stratmann, F.: Homogeneous and heterogeneous ice nucleation at LACIS: operating principle and theoretical studies, Atmos. Chem. Phys., 11, 1753-1767, doi:10.5194/acp-11-1753-2011, 2011. 
Hartmann, S., Augustin, S., Clauss, T., Wex, H., Šantl-Temkiv, T., Voigtländer, J., Niedermeier, D., and Stratmann, F.: Immersion freezing of ice nucleation active protein complexes, Atmos. Chem. Phys., 13, 5751-5766, doi:10.5194/acp-13-57512013, 2013.

Hartmann, S., Wex, H., Clauß, T., Augustin-Bauditz, S., Niedermeier, D., Rösch, M., and Stratmann, F.: Immersion freezing of kaolinite: Scaling with particle surface area, J. Atmos. Sci., 73, 263-278, 2016.

Havlíček, D., Přibil, R., and Kratochvíl, B.: Content of quartz and mullite in some selected power-plant fly ash in Czechoslovakia, Atmos. Environ., 23, 701-706, 1989.

Havlíček, D., Přibil, R., and Školoud, O.: The chemical and mineralogical composition of the water-soluble fraction of power-plant ash and its effect on the process of crystallization of water, Atmos. Environ., 27A, 655-660, 1993.

Hellner, L.: Untersuchungen des Immersionsgefrierverhaltens natürlicher Böden am Leipzig Aerosol and Cloud Interaction Simulator (LACIS), Master's thesis, University of Leipzig, 2015.

Herich, H., Tritscher, T., Wiacek, A., Gysel, M., Weingartner, E., Lohmann, U., Baltensperger, U., and Cziczo, D. J.: Water uptake of clay and desert dust aerosol particles at sub- and supersaturated water vapor conditions, Phys. Chem. Chem. Phys., 11, 7804-7809, 2009.

Heymsfield, A. and Willis, P.: Cloud conditions favoring secondary ice particle production in tropical maritime convection, J. Atmos. Sci., 71, 4500-4526, 2014.

Hicks, S. and Isaksson, E.: Assessing source areas of pollutants from studies of fly ash, charcoal, and pollen from Svalbard snow and ice, J. Geophys. Res., 111, D02113, doi:10.1029/2005JD006167, 2006.

Hinds, W. C.: Aerosol Technology: Properties, Behavior, and Measurements of Airborne Particles, John Wiley \& Sons, Inc., 1999.

Hinneburg, D., Renner, E., and Wolke, R.: Formation of secondary inorganic aerosols by power plant emissions exhausted through cooling towers in Saxony, Environ. Sci. Pollut. Res., 16, 25-35, 2009.

Hiranuma, N., Brooks, S. D., Auvermann, B. W., and Littleton, R.: Using environmental scanning electron microscopy to determine the hygroscopic properties of agricultural aerosols, Atmos. Environ., 42, 1983-1994, 2008.

Hiranuma, N., Hoffmann, N., Kiselev, A., Dreyer, A., Zhang, K., Kulkarni, G., Koop, T., and Möhler, O.: Influence of surface morphology on the immersion mode ice nucleation efficiency of hematite particles, Atmos. Chem. Phys., 14, 2315-2324, doi:10.5194/acp-14-2315-2014, 2014.

Hiranuma, N., Augustin-Bauditz, S., Bingemer, H., Budke, C., Curtius, J., Danielczok, A., Diehl, K., Dreischmeier, K., Ebert, M., Frank, F., Hoffmann, N., Kandler, K., Kiselev, A., Koop, T., Leisner, T., Möhler, O., Nillius, B., Peckhaus, A., Rose, D., Weinbruch, S., Wex, H., Boose, Y., DeMott, P. J., Hader, J. D., Hill, T. C. J., Kanji, Z. A., Kulkarni, G., Levin, E. J. T., McCluskey, C. S., Murakami, M., Murray, B. J., Niedermeier, D., Petters, M. D., O’Sullivan, D., Saito, A., Schill, G. P., Tajiri, T., Tolbert, M. A., Welti, A., Whale, T. F., Wright, T. P., and Yamashita, K.: A comprehensive laboratory study on the immersion freezing behavior of illite NX particles: a comparison of 17 ice nucleation measurement techniques, Atmos. Chem. Phys., 15, 2489-2518, doi:10.5194/acp-15-2489-2015, 2015.
Ignatius, K., Kristensen, T. B., Järvinen, E., Nichman, L., Fuchs, C., Gordon, H., Herenz, P., Hoyle, C. R., Duplissy, J., Garimella, S., Dias, A., Frege, C., Höppel, N., Tröstl, J., Wagner, R., Yan, C., Amorim, A., Baltensperger, U., Curtius, J., Donahue, N. M., Gallagher, M. W., Kirkby, J., Kulmala, M., Möhler, O., Saathoff, H., Schnaiter, M., Tomé, A., Virtanen, A., Worsnop, D., and Stratmann, F.: Heterogeneous ice nucleation of viscous secondary organic aerosol produced from ozonolysis of $\alpha$-pinene, Atmos. Chem. Phys., 16, 6495-6509, doi:10.5194/acp-16-6495-2016, 2016.

International Energy Agency: World Energy Outlook, available at: https://www.iea.org/publications/freepublications/publication/ english.pdf (last access: 19 October 2016), 2012.

Isono, K., Komabayasi, M., and Ono, A.: Volcanoes as a source of atmospheric ice nuclei, Nature, 183, 318-318, 1959.

Kaaden, N., Massling, A., Schladitz, A., Müller, T., Kandler, K., Schütz, L., Weinzierl, B., Petzold, A., Tesche, M., Leinert, S., Deutscher, C., Ebert, M., Weinbruch, S., and Wiedensohler, A.: State of mixing, shape factor, number size distribution, and hygroscopic growth of the Saharan anthropogenic and mineral dust aerosol at Tinfou, Morocco, Tellus, 61B, 51-63, 2009.

Kalyoncu, R. S. and Olson, D. W.: Coal combustion products, Tech. rep., US Department of the Interior, US Geological Survey, 2001.

Kaufherr, N. and Lichtman, D.: Comparison of micron and submicron fly ash particles using scanning electron micropscopy and X-ray elemental analysis, Environ. Sci. Technol., 18, 544-547, 1984.

Kim, Y. Y., Kulak, A. N., Li, Y., Batten, T., Kuball, M., Armes, S. P., and Meldrum, F. C.: Substrate-directed formation of calcium carbonate fibres, J. Material. Chem., 19, 387-398, 2009.

Knudson, E. O. and Whitby, K. T.: Aerosol classification by electric mobility: Apparatus, theory and applications, J. Aerosol Sci., 6, 443-451, 1975.

Koop, T. and Zobrist, B.: Parameterizations for ice nucleation in biological and atmospheric systems, Phys. Chem. Chem. Phys., 11, 10839-10850, 2009.

Koop, T., Luo, B., Tsias, A., and Peter, T.: Water activity as the determiant for homogeneous ice nucleation in aqueous solutions, Nature, 406, 611-614, 2000.

Kucbel, M., Sýkorová, B., and Růžičková, J.: Carbonaceous particles in the air of the Moravian-Silesian Region, Czech Republic, Perspectives in Science, 7, 333-336, 2016.

Kulkarni, G., Nandasiri, M., Zelenyuk, A., Beranek, J., Madaan, N., Devaraj, A., Shutthanandan, V., Thevuthasan, S., and Varga, T.: Effects of crystallographic properties on the ice nucleation properties of volcanic ash, Geophys. Res. Lett., 42, 3048-3055, 2015.

Li, W. and Shao, L.: Transmission electron microscopy study of aerosol particles from the brown hazes in northern China, J. Geophys. Res., 114, D09302, doi:10.1029/2008JD011285, 2009.

Mason, B. J. and van den Heuvel, A. P.: The properties and behavior of some artificial ice nuclei, Proceedings of the Physical Society, 74, 744-755, 1959.

McCluskey, C. S., DeMott, P. J., Prenni, A. J., Levin, E. J., McMeeking, G. R., Sullivan, A. P., Hill, T. C., Nakao, S., Carrico, C. M., and Kreidenweis, S. M.: Characteristics of atmospheric ice nucleating particles associated with biomass burning in the US: Prescribed burns and wildfires, J. Geophys. Res., 119, 10458-10470, 2014. 
Mueller, S. F., Mallard, J. W., Mao, Q., and Shaw, S. L.: Fugitive particulate emission factors for dry fly ash disposal, J. Air Waste Manage. Assoc., 63, 806-818, 2013.

Murray, B. J., Broadley, S. L., Wilson, T. W., Bull, S. J., Wills, R. H., Christenson, H. K., and Murray, E. J.: Kinetics of the homogeneous freezing of water, Phys. Chem. Chem. Phys., 12, 10380 10387, 2010a.

Murray, B. J., Wilson, T. W., Dobbie, S., Cui, Z., Al-Jumur, S. M. R. K., Möhler, O., Schnaiter, M., Wagner, R., Benz, S., Niemand, M., Saathoff, H., Ebert, V., Wagner, S., and Kärcher, B.: Heterogeneous nucleation of ice particles on glassy aerosols under cirrus conditions, Nature Geosci., 3, 233-237, 2010 b.

Naik, T. R., Kraus, R. N., and Kumar, R.: Wood ash: A new source of pozzolanic material, Tech. Rep. CBU-200110, Center for by-products utilization, University of Wisconsin, available at: https://www4.uwm.edu/cbu/Papers/2001\% 20CBU\%20Reports/CBU\%202001-10.pdf (last access: 19 October 2016), 2001.

Niedermeier, D., Augustin-Bauditz, S., Hartmann, S., Wex, H., Ignatius, K., and Stratmann, F.: Can we define an asymptotic value for the ice active surface site density for heterogeneous ice nucleation?, J. Geophys. Res.-Atmos., 102, 5036-5046, 2015.

Niemand, M., Möhler, O., Vogel, B., Vogel, H., Hoose, C., Connolly, P., Klein, H., Bingemer, H., DeMott, P., Skrotzki, J., and Leisner, T.: A particle-surface-area-based parameterization of immersion freezing on desert dust particles, J. Atmos. Sci., 69, 3077-3092, 2012.

Oorts, K., Vanlauwe, B., Recous, S., and Merckx, R.: Redistribution of particulate organic matter during ultrasonic dispersion of highly weathered soils, European Journal of Soil Science, 56, 77-91, 2005.

O’Sullivan, D., Murray, B. J., Ross, J. F., Whale, T. F., Price, H. C., Atkinson, J. D., Umo, N. S., and Webb, M. E.: The relevance of nanoscale biological fragments for ice nucleation in clouds, Scientific Reports, 5, No. 8082, 2015.

Parungo, F. P., Ackerman, E., Proulx, H., and Pueschel, R. F.: Nucleation properties of fly ash in a coal-fired power-plant plume, Atmos. Environ., 12, 929-935, 1978a.

Parungo, F. P., Allee, P. A., and Weickmann, H. K.: Snowfall induced by a power plant plume, Geophys. Res. Lett., 5, 515-517, 1978b.

Peckhaus, A., Kiselev, A., Hiron, T., Ebert, M., and Leisner, T.: A comparative study of K-rich and $\mathrm{Na} / \mathrm{Ca}$-rich feldspar ice-nucleating particles in a nanoliter droplet freezing assay, Atmos. Chem. Phys., 16, 11477-11496, doi:10.5194/acp-1611477-2016, 2016.

Petters, M. D. and Wright, T. P.: Revisiting ice nucleation from precipitation samples, Geophys. Res. Lett., 42, 8758-8766, 2015.

Petters, M. D., Parsons, M. T., Prenni, A. J., DeMott, P. J., Kreidenweis, S. M., Carrico, C. M., Sullivan, A. P., McMeeking, G. R., Levin, E., Wold, C. E., Collett, J. L. J., and Moosmüller, H.: Ice nuclei emissions from biomass burning, J. Geophys. Res., 114, D07209, doi:10.1029/2008JD011532, 2009.

Pinti, V., Marcolli, C., Zobrist, B., Hoyle, C. R., and Peter, T.: Ice nucleation efficiency of clay minerals in the immersion mode, Atmos. Chem. Phys., 12, 5859-5878, doi:10.5194/acp-12-58592012, 2012.

Plummer, L. N. and Busenberg, E.: The solubilities of calcite, aragonite and vaterite in $\mathrm{CO}_{2}-\mathrm{H}_{2} \mathrm{O}$ solutions between $0{ }^{\circ} \mathrm{C}$ and $90^{\circ} \mathrm{C}$, and an evaluation of the aqueous model for the system $\mathrm{CaCO}_{3}-\mathrm{CO}_{2}-\mathrm{H}_{2} \mathrm{O}$, Geochim. Cosmochim. Acta, 46, 10111040, 1982.

Prenni, A. J., DeMott, P. J., Sullivan, A. P., Sullivan, R. C., Kreidenweis, S. M., and Rogers, D. C.: Biomass burning as a potential source for atmospheric ice nuclei: Western wildfires and prescribed burns, Geophys. Res. Lett., 39, L11805, doi:10.1029/2012GL051915, 2012.

Pruppacher, H. R. and Klett, J. D.: Microphysics of Clouds and Precipitation, Kluwer Academic Publishers, 1997.

Pruppacher, H. R. and Sänger, R.: Mechanismus der Vereisung unterkühlter Wassertropfen durch disperse Keimsubstanzen, Zeitschrift für Angewandte Mathematik und Physik, 6, 407-416, 1955.

Pueschel, R. F., Schnell, R. C., Weickmann, H. K., and Wellman, D. L.: Aerosol and ice nuclei measurements in the plume of the Homer City, PA, power plant, Geophys. Res. Lett., 6, 371-374, 1979.

Querol, X., Alastuey, A., Lopez-Soler, A., Mantilla, E., and Plana, F.: Mineral composition of atmospheric particulates around a large coal-fired power station, Atmos. Environ., 30, 3557-3572, 1996.

Ramsden, A. R. and Shibaoka, M.: Characterization and analysis of individual fly-ash particles from coal-fired power stations by a combination of optical microscopy, electron microscopy and quantitative electron microprobe analysis, Atmos. Environ., 16, 2191-2206, 1982.

Roberts, G. C. and Nenes, A.: A continuous-flow streamwise thermal-gradient $\mathrm{CCN}$ chamber for atmospheric measurements, Aerosol Sci. Technol., 39, 206-221, 2005.

Rogers, D. C., DeMott, P. J., Kreidenweis, S. M., and Chen, Y.: Measurements of ice nucleating aerosols during SUCCESS, Geophys. Res. Lett., 25, 1383-1386, 1998.

Rösch, M.: Untersuchungen zur Generierung und zum Immersionsgefrierverhalten supermikroner, quasimonodisperser Mineralstaubpartikel, Ph.D. thesis, University of Leipzig, 2015.

Rose, N. L., Jones, V. J., Noon, P. E., Hodgson, D. A., Flower, R. J., and Appleby, P. G.: Long-range transport of pollutants to the Falkland Islands and Antarctica: Evidence from lake sediment fly ash particle records, Environ. Sci. Technol., 46, 9881-9889, 2012.

Rosenfeld, D. and Woodley, W. L.: Deep convective clouds with sustained supercooled liquid water down to $-37.5^{\circ} \mathrm{C}$, Nature, 405, 440-442, 2000.

Schäfer, V. J.: The Changing Global Environment, chap. The inadvertent modification of the atmosphere by air pollution, 177-196, Springer Netherlands, 1975.

Schnell, R. C., Valin, C. C. V., and Pueschel, R. F.: Atmospheric ice nuclei: No detectable effect from a coal-fired powerpower plume, Geophys. Res. Lett., 3, 657-660, 1976.

Seinfeld, J. H. and Pandis, S. N.: Atmospheric Chemistry and Physics: From Air Pollution to Climate Change, John Wiley \& Sons, Inc., 2006.

Shen, J. H., Klier, K., and Zettlemoyer, C.: Ice Nucleation by Micas, J. Atmos. Sci., 34, 957-960, 1977.

Shoumkova, A., Tsacheva, T., Stoyanova, V., Grancharov, I., Shumkov, S., and Marinov, M.: Physico-chemical and morphological properties of coal fly ash from Varna power plant, Bul- 
garia, in: Proceedings of the Third International Conference on Ecological Chemistry, 560-570, 2005.

Smil, V.: Energy in Nature and Society: General Energetics of Complex Systems, MIT Press, 2008.

Smith, R. D., Campbell, J. A., and Nielson, K. K.: Concentration dependence upon particle size of volatilized elements in fly ash, Environ. Sci. Technol., 13, 553-558, 1979.

Steenari, B. M., Karlsson, L. G., and Lindqvist, O.: Evaluation of the leaching characteristics of wood ash and the influence of ash agglomeration, Biomass and Bioenergy, 16, 119-136, 1999a.

Steenari, B. M., Schelander, S., and Lindqvist, O.: Chemical and leaching characteristics of ash from combustion of coal, peat and wood in a 12 MW CFB - A comparative study, Fuel, 78, 249258, 1999b.

Stetzer, O., Baschek, B., Lüönd, F., and Lohmann, U.: The Zurich Ice Nucleation Chamber (ZINC) - A new instrument to investigate atmospheric ice nucleation, Aerosol Sci. Technol., 42, 6474, 2008.

Sullivan, R. C., Moore, M. J. K., Petters, M. D., Kreidenweis, S. M., Roberts, G. C., and Prather, K. A.: Effect of chemical mixing state on the hygroscopicity and cloud nucleation properties of calcium mineral dust particles, Atmos. Chem. Phys., 9, 33033316, doi:10.5194/acp-9-3303-2009, 2009.

Sullivan, R. C., Moore, M. J. K., Petters, M. D., Kreidenweis, S. M., Qafoku, O., Laskin, A., Roberts, G. C., and Prather, K. A.: Impact of particle generation method on the apparent hygroscopicity of insoluble mineral particles, Aerosol Sci. Technol., 44, 830-846, 2010.

Szyrmer, W. and Zawadzki, I.: Biogenic and anthropogenic sources of ice-forming nuclei: A review, B. Am. Meteorol. Soc., 78, 209228, 1997.

Textor, C., Schulz, M., Guibert, S., Kinne, S., Balkanski, Y., Bauer, S., Berntsen, T., Berglen, T., Boucher, O., Chin, M., Dentener, F., Diehl, T., Easter, R., Feichter, H., Fillmore, D., Ghan, S., Ginoux, P., Gong, S., Grini, A., Hendricks, J., Horowitz, L., Huang, P., Isaksen, I., Iversen, I., Kloster, S., Koch, D., Kirkevåg, A., Kristjansson, J. E., Krol, M., Lauer, A., Lamarque, J. F., Liu, X., Montanaro, V., Myhre, G., Penner, J., Pitari, G., Reddy, S., Seland, $\varnothing .$, Stier, P., Takemura, T., and Tie, X.: Analysis and quantification of the diversities of aerosol life cycles within AeroCom, Atmos. Chem. Phys., 6, 1777-1813, doi:10.5194/acp-6-1777-2006, 2006.

Umbría, A., Galán, M., Muñoz, M. J., and Martín, R.: Characterization of atmospheric particles: An analysis of particles in the Campo de Gibraltar, Atmósfera, 191-206, 2004.

Umo, N. S., Murray, B. J., Baeza-Romero, M. T., Jones, J. M., LeaLangton, A. R., Malkin, T. L., O’Sullivan, D., Neve, L., Plane, J. M. C., and Williams, A.: Ice nucleation by combustion ash particles at conditions relevant to mixed-phase clouds, Atmos. Chem. Phys., 15, 5195-5210, doi:10.5194/acp-15-5195-2015, 2015.

U.S. Department of Transportation: User guidelines for waste and byproduct materials in pavement construction, Tech. Rep. FHWA-RD-97-148, Federal Highway Administration, available at: http://www.ewp.rpi.edu/hartford/ ernesto/ S2014/SHWPCE/Papers/SW-Incineration-Gasification/ US-DoT-FHA-MSW-IncineratorAsh-Uses.pdf (last access: 19 October 19 2016), 1998.
Vali, G.: Quantitative evaluation of experimental results on the heterogeneous freezing nucleation of supercooled liquids, J. Atmos. Sci., 28, 402-409, 1971.

Welti, A., Lüönd, F., Stetzer, O., and Lohmann, U.: Influence of particle size on the ice nucleating ability of mineral dusts, Atmos. Chem. Phys., 9, 6705-6715, doi:10.5194/acp-9-6705-2009, 2009.

Welti, A., Lüönd, F., Kanji, Z. A., Stetzer, O., and Lohmann, U.: Time dependence of immersion freezing: an experimental study on size selected kaolinite particles, Atmos. Chem. Phys., 12, 9893-9907, doi:10.5194/acp-12-9893-2012, 2012.

Wex, H., DeMott, P. J., Tobo, Y., Hartmann, S., Rösch, M., Clauss, T., Tomsche, L., Niedermeier, D., and Stratmann, F.: Kaolinite particles as ice nuclei: learning from the use of different kaolinite samples and different coatings, Atmos. Chem. Phys., 14, 55295546, doi:10.5194/acp-14-5529-2014, 2014.

Whale, T. F., Murray, B. J., O’Sullivan, D., Wilson, T. W., Umo, N. S., Baustian, K. J., Atkinson, J. D., Workneh, D. A., and Morris, G. J.: A technique for quantifying heterogeneous ice nucleation in microlitre supercooled water droplets, Atmos. Meas. Tech., 8, 2437-2447, doi:10.5194/amt-8-2437-2015, 2015.

Wheeler, M. J., Mason, R. H., Steunenberg, K., Wagstaff, M., Chou, C., and K., A.: Immersion freezing of supermicron mineral dust particles: Freezing results, testing different schemes for describing ice nucleation, and ice nucleation active site densities, J. Phys. Chem. A, 119, 4358-4372, 2014.

Wiedensohler, A.: An approximation of the bipolar charge distribution for particles in the submicron size range, J. Aerosol Sci., 19, 387-389, 1988.

Wilson, T. W., Murray, B. J., Wagner, R., Möhler, O., Saathoff, H., Schnaiter, M., Skrotzki, J., Price, H. C., Malkin, T. L., Dobbie, S., and Al-Jumur, S. M. R. K.: Glassy aerosols with a range of compositions nucleate ice heterogeneously at cirrus temperatures, Atmos. Chem. Phys., 12, 8611-8632, doi:10.5194/acp-128611-2012, 2012.

Yakobi-Hancock, J. D., Ladino, L. A., and Abbatt, J. P. D.: Feldspar minerals as efficient deposition ice nuclei, Atmos. Chem. Phys., 13, 11175-11185, doi:10.5194/acp-13-11175-2013, 2013.

Zhang, X., Wu, G., Yao, T., Zhang, C., and Yue, Y.: Characterization of individual fly ash particles in surface snow at Urumqi Glacier No. 1, Eastern Tianshan, Chinese Sci. Bull., 56, 34643473, 2011.

Zheng, J. and Yamada, M.: Inductively coupled plasma-sector field mass spectrometry with a high-efficiency sample introduction system for the determination of $\mathrm{Pu}$ isotopes in settling particles at femtogram levels, Talanta, 69, 1246-1253, 2006.

Zimmermann, F., Weinbruch, S., Schütz, L., Hofmann, H., Ebert, M., Kandler, K., and Worringen, A.: Ice nucleation properties of the most abundant mineral dust phases, J. Geophys. Res., 113, D23204, doi:10.1029/2008JD010655, 2008.

Zobrist, B., Marcolli, C., Peter, T., and Koop, T.: Heterogeneous ice nucleation in aqueous solutions: The role of water activity, J. Phys. Chem. A, 112, 3965-3975, 2008.

Zolles, T., Burkart, J., Häusler, T., Pummer, B., Hitzenberger, R., and Grothe, H.: Identification of ice nucleation active sites on feldspar dust particles, J. Phys. Chem. A, 119, 2692-2700, 2015. 